\title{
CONSTRUÇÃO JURÍDICA DO REGIME DE EXCEÇÃO NO BRAS̃IL: UM ESBOÇO PARA COMPREENDER A JUSTIÇA DE TRANSIÇÃO
}

Adriano Portella de Amorim*

SUMÁRIO: Introdução; 2 Entre uma Pretensa Democracia e o Limiar de um Regime de Exceção; 3 A Instalação da Ditadura: Fundamentos Jurídicos e Políticos; 40 Regime de Exceção e a Carta de 1967; 5 Considerações Finais; Referências.

RESUMO: O presente artigo tem o objetivo de apresentar o conjunto normativo que fundamentou a implantação do regime de exceção no Brasil a partir de 1964, com a finalidade de identificar argumentos e valores que tenham determinado a construção da legitimidade, a assunção do poder constituinte e a alegada exclusão de ilicitudes por atos praticados, tudo com a intenção de reunir elementos para abordar os possíveis mecanismos de uma justiça de transição. Para tanto, a abordagem metodológica empregada consistiu especialmente na análise de dispositivos das constituições de 1946 e 1967, além de emendas às citadas constituições, atos complementares, atos institucionais e legislação infraconstitucional; naturalmente, também foram utilizadas as contribuições teóricas que consubstanciaram a compreensão da temática proposta. As conclusões preliminares que resultam do presente artigo indicam que a construção política e jurídica do regime de exceção foi estrategicamente desenvolvida para o fim de assegurar legitimidade e constitucionalidade aos mecanismos de poder que se fundamentaram no argumento revolucionário, o que dificulta a adoção de mecanismos destinados a uma justiça de transição que transcenda a Lei de Anistia. As limitações do presente estudo decorrem da necessidade de ampliar os aspectos históricos que lhe são inerentes, bem como avançar na análise jurisprudencial e das iniciativas contemporâneas no campo político.

PALAVRAS-CHAVE: Constituição; Poder político; Regime de exceção.

\section{LEGAL CONSTRUCTION OF EXCEPTION SCHEME IN BRAZIL: AN OUTLINE FOR UNDERSTANDING THE TRANSITION OF JUSTICE}

ABSTRACT: This article aims to present the set of rules that justified the implementation of the authoritarian regime in Brazil since 1964, in order to identify arguments and values that have determined the construction of legitimacy, the assumption of

Doutorando no Programa de Doutorado em Direito do Centro Universitário de Brasília (UniCEUB), Brasília, Brasil; Docente do Curso de Direito das Faculdades Integradas Promove de Brasília, Brasil. Líder do Grupo de Pesquisa de Direitos Fundamentais e Políticas Públicas; Brasil. E-mail: portelladeamorim@gmail.com 
constituent power and the alleged exclusion of illegal activity by acts performed, all with the intention of bringing together elements address the possible mechanisms of transitional justice. Therefore, the methodological approach used consisted especially in the constitutions analysis devices 1946 and 1967, and amendments to the constitutions, complementary acts, institutional acts and constitutional legislation; of course, were also used the theoretical contributions that substantiated by understanding the proposed theme. The preliminary findings resulting from this article show that a political and legal construction of the authoritarian regime was strategically developed to ensure legitimacy and constitutionality to the mechanisms of power that was based on the revolutionary argument, which hinders the adoption of mechanisms to a transition of justice that transcends the Amnesty Act. The limitations of this study stem from the need to expand the historical aspects that are inherent as well as advance the jurisprudential analysis and contemporary initiatives in the political field.

KEY WORDS: Authoritarian regime; Constitution; Political power.

\section{CONSTRUCCIÓN JURÍDICA DEL REGIMEN DE EXCEPCIÓN EN BRASIL: UN BOSQUEJO PARA COMPRENDER LA JUSTICIA DE TRANSICIÓN}

RESUMEN: El presente artículo tiene como objetivo presentar el conjunto normativo que fundamentó la implantación del régimen de excepción en Brasil a partir de 1964, con la finalidad de identificar argumentos y valores que determinaron la construcción de la legitimidad, la asunción del poder constituyente y la alegada exclusión de ilicitudes por actos practicados, todo con la intención de reunir elementos para abordar los posibles mecanismos de una justicia de transición. Para tanto, el abordaje metodológico empleado consistió especialmente en el análisis de dispositivos de las constituciones de 1946 y 1967, además de emendas a las citadas constituciones, actos complementares, actos institucionales y legislación infra constitucional; naturalmente, también fueron utilizadas las contribuciones teóricas que consubstanciaron la comprensión temática propuesta. Las conclusiones preliminares que resultan del presente desarrolladas con la finalidad de asegurar legitimidad y constitucionalidad a los mecanismos de poder que se fundamentaron en el argumento revolucionario, lo que dificulta la adopción de mecanismos destinados a una justicia de transición que trascienda la Ley de Amnistía. Las limitaciones del presente estudio son decurrentes de la necesidad de ampliar los aspectos históricos que le son inherentes, bien como avanzar en el análisis jurisprudencial y de las iniciativas contemporáneas en el campo político.

PALABRAS-CLAVE: Constitución; Poder político; Régimen de Excepción. 


\section{INTRODUÇÃO}

Três décadas de redemocratização no Brasil ainda não foram suficientes para que indivíduos, Estado e sociedade superassem plenamente os efeitos dos momentos políticos, dos conflitos e dos atos institucionais que marcaram a história brasileira desde 1969, especialmente. O regime militar deixou o centro do poder, que foi transferido ao poder civil, às instituições políticas e às escolhas da sociedade, por meio de eleições, inclusive para a elaboração da nova Carta Política. O processo de consolidação democrática segue seu curso, com base nas regras do estado de direito, da alternância e da temporalidade do exercício do poder político. A nova ordem constitucional estabelecida pela Constituição de 1988 reconstruiu e restringiu o papel, os limites de atuação e a subordinação das Forças Armadas, proporcionando os mecanismos jurídicos indispensáveis à reconciliação, à convivência pacífica entre correntes ideológicas diferentes. Porém, é inegável que o conjunto normativo vigente ainda não foi capaz de proporcionar a plena estabilização entre as correntes de pensamento divergentes, pois a remansosa sensação de reparação e de reconhecimento de atos de injustiça não se afastou dos argumentos políticos e jurídicos que estão presentes nos debates contemporâneos.

Nesse sentido, na transição entre o regime de exceção e a democracia, a anistia, concebida como a ponte entre antigo e novo, o instrumento de segurança jurídica que permitiria a travessia fundamentada no consenso e na conciliação, no recomeço sem punição, ainda flutua sobre as nuances do decisionismo e do tecnicismo jurídicos, os quais, na prática, não são orientados simplesmente pela norma positivada, mas sim pelo pensamento político predominante que transita entre ideologias e interpretações judiciais. Compreender a construção dessa dinâmica de argumentos que interagem e do modelo jurídico adotado para a implantação do regime de exceção de 1969 constitui o caminho para a reparação de danos e o reconhecimento, para a formação de amplos consensos a respeito das escolhas da sociedade brasileira e que possam somar ao amadurecimento do processo de consolidação democrática do país.

É nessa perspectiva que a presente abordagem se desenvolve, com a modesta pretensão de discutir elementos que possam contribuir para compreensão, ao menos em parte, das idiossincrasias que transitam entre os sentimentos de perdão incondicional e de justiça para além da norma escrita, isto é, a justiça de 
transição no contexto da redemocratização do Brasil, que se dilui em gerações que não esquecem e outras que desconhecem os fatos políticos e jurídicos que ainda repercutem na sociedade, no direito e no Estado. Para atender a esse cenário, o presente artigo se dedicará à análise dos fundamentos jurídicos que delinearam os atos institucionais do regime de exceção estabelecido em 1969. Portanto, a análise estará limitada aos dispositivos constitucionais das constituições de 1946 e de 1967, além de comentários a respeito de alguns atos institucionais que efetivamente implantaram a ditadura brasileira mais recente.

A escolha metodológica do presente artigo é demonstrar, a partir da leitura dos textos constitucionais, como o estado de latência, de preocupação com as vulnerabilidades internas do país e com a segurança nacional mobilizaram os esforços políticos do país, a ponto de implantar um estado de vigilância permanente contra inimigos internos, redirecionando a atuação precípua e fundamental das Forças Armadas e das instituições militares, que passaram a se preocupar não apenas dos ataques efetivos e potenciais - os convencionais conflitos armados - de natureza externa, para dirigir seus esforços para evitar uma pretensa ruptura interna.

Uma advertência: o reconhecimento da natureza modesta da presente abordagem, ao tempo em que revela a necessidade de sua continuada revisão, traz consigo a convicção de que as escolhas argumentativas, ante a complexidade do tema, merecem permanente reflexão, crítica, aprimoramento e complementação, o que se dará pelo debate acadêmico.

\section{ENTRE UMA PRETENSA DEMOCRACIA E O LIMIAR DE UM REGIME DE EX- CEÇÃO}

Para compreender as mudanças políticas e sociais pelas quais o Brasil passou é importante compreender o desenho da normatividade constitucional que vigorou no país, observando-se a sutileza de determinados dispositivos das constituições de 1946 e de 1967, antes mesmo da instituição mais aguda do regime de exceção, que se deu na forma dos atos institucionais perpetrados a partir de 09 de abril de $1964^{2}$. Nessa breve abordagem, o objetivo mais relevante consiste em extrair o modelo de

\footnotetext{
${ }^{2}$ Tendo como marco o Ato Institucional $\mathrm{n}^{\circ} 1$, de 09 de abril de 1964, que modificou as regras de eleição, mandato e poderes do Presidente da República, conferindo aos comandantes-em-chefe das Forças Armadas o poder de suspender direitos políticos e cassar mandatos legislativos excluída a apreciação judicial.
} 
valor político que predominou na orientação das instituições incumbidas da tarefa de proteger a sociedade e o Estado, o que se consagrou na chamada doutrina da segurança nacional ${ }^{3}$ a respeito da qual voltaremos a abordar mais adiante.

A denominada Assembleia Constituinte que promulgou a então Constituição dos Estados Unidos do Brasil, de 18 de setembro de 19464, o fez com o textual propósito de organizar um regime democrático, conforme consta expressamente da parte preambular da Carta: "Nós, os representantes do povo brasileiro, reunidos, sob a proteção de Deus, em Assembleia Constituinte para organizar um regime democrático, decretamos e promulgamos a seguinte...". A palavra democracia somente é mencionada novamente no $\S 13$ do art. 141 do texto constitucional quando tratou dos direitos e das garantias individuais ao determinar que "É vedada a organização, o registro ou o funcionamento de qualquer Partido Político ou associação, cujo programa ou ação contrarie o regime democrático, baseado na pluralidade dos Partidos e na garantia dos direitos fundamentais do homem".

Entretanto, é relevante notar a intensa preocupação do denominado poder constituinte em prever no texto constitucional um conjunto de mecanismos destinados a garantir a preservação do regime democrático, donde se constata que a ameaça à democracia constituiu mais do que ritualística procedimental, mas sim tema de fundamental importância para a nova Carta Política que se promulgava. Mas, de que tipo de democracia se tratava?5 Para melhor compreensão, é importante destacar alguns dos mais interessantes dispositivos. A competência para declarar a guerra e fazer a paz, para decretar, prorrogar e suspender o estado de sítio, bem como para organizar as forças armadas, a segurança das fronteiras e a defesa externa do país foram concentradas na União $0^{6}$, enquanto que se previu, como crime de responsabilidade do Presidente da República, os atos que atentassem contra a Constituição Federal e a segurança interna do país ${ }^{7}$. Interessa destacar que, na

\footnotetext{
${ }_{3}$ A doutrina de segurança nacional encontra-se substanciada na Lei $\mathrm{n}^{0} 7.170$, de 14 de dezembro de 1983. Define os crimes contra a segurança nacional, a ordem política e social, estabelece seu processo e julgamento e dá outras providências. Disponível em: < http://www.planalto.gov.br/ccivil_03/_Ato2007-2010/2009/Decreto/ D7037.htm > . Acesso em: 19 fev. 2016.

${ }^{4}$ Em vigor em 19 de setembro de 1946, quando Eurico Gaspar Dutra era o Presidente da República (31 de janeiro de 1946 a 31 de janeiro de 1951).

${ }^{5}$ Em abordagens que seguirão a presente, pretendemos estabelecer uma ponte entre a situação brasileira e o cenário internacional de polarização entre os Estados Unidos da América e a então União das Repúblicas Socialistas Soviéticas (ou seja, entre direita e esquerda), decorrente da Segunda Guerra Mundial. A propósito, é a partir desse conflito mundial que encontramos a gênese da "justiça de transição" para a condenação dos alemães em Nuremberg, sendo relevante a abordagem feita por Hannah Arendt (Origens do totalitarismo: antissemitismo, imperialismo, totalitarismo. São Paulo: Companhia das Letras, 2013).

${ }^{6}$ Art. $5^{\circ}$, incisos II, III e IV da Constituição de 1946.

Art. 89, caput e inciso IV da Constituição de 1946.
} 
concepção excepcional que fundamentou a ideia de segurança nacional, o foro especial da justiça militar alcançou os "civis" para os casos de repressão de crimes contra a segurança nacional ou contra as instituições militares, afastando da justiça comum o processo e o julgamento desses crimes $^{8}$. Note-se que a persecução penal, que exige o devido processo legal, é tratada nesse momento com o uso do termo "repressão".

Nessa ordem de ideias, a Constituição de 1946 caracterizou as Forças Armadas como instituições nacionais permanentes, sob a autoridade suprema do Presidente da República, destinadas a defender a pátria e a garantir os poderes constitucionais, a lei e a ordem ${ }^{9}$, cabendo-lhes, juntamente com o Conselho de Segurança Nacional, o trato dos "problemas relativos à defesa do País"10. Nos termos do $\S 1^{\circ}$ do art. 179 da Constituição de 1946, aquele Conselho era dirigido pelo Presidente da República e integrado pelos ministros de Estado e chefes de EstadoMaior (militares), na qualidade de membros efetivos. Por sua vez, o art. 183 da Carta considerou como forças auxiliares e reservas do Exército as polícias militares dos Estados, dos Territórios e do Distrito Federal. Tal circunstância ainda na atualidade é objeto de crítica ${ }^{11}$, sob o argumento de que o dispositivo constitucional estendeu aos órgãos de segurança pública a doutrina de segurança nacional de repressão a movimentos subversivos internos, o que teria contribuído para a deturpação dos postulados de direitos humanos, notadamente porque o enfrentamento a cargo das Forças Armadas deve se dirigir a inimigos externos sujeitos ao limite da violência legalizada, ou seja, até mesmo a eventual morte decorrente do combate, mesmo que observados os princípios dos tratados internacionais e o Direito Internacional Humanitário aplicável aos Conflitos Armados ${ }^{12}$.

A redação original do art. 108, $\S 1^{\circ}$ da Constituição de 1946 apresentava terminologia de vanguarda que atribuía às Forças Armadas a atividade de defesa nacional, ligada a uma das finalidades precípuas do Estado em face dos indivíduos e da sociedade, que é a de proporcionar proteção externa contra ataques ou ameaças efetivas ou potenciais. $\mathrm{O}$ redirecionamento das instituições militares à segurança

${ }^{8}$ Art. 108, $\S 1^{\circ}$ da Constituição de 1946, com a redação dada pelo Ato Institucional $n^{\circ} 2$, de 27 de outubro de 1965.

9 Arts. 176 e 177 da Constituição de 1946.

${ }^{10}$ Art. 179, caput, da Constituição de 1946.

${ }^{11}$ A esse respeito é interessante observar o estabelecido no Programa Nacional de Direitos Humanos - PNDH-3, na forma do atual Decreto $\mathrm{n}^{0} 7.037$, de 21 de dezembro de 2009.

${ }^{12}$ Decreto ${ }^{\circ} 849$, de 25 de junho de 1993. 
nacional, aos conflitos internos, à repressão contra atos políticos subversivos mudou a face do ordenamento jurídico e somente veio a arrefecer no pós-exceção, a partir de cujo momento histórico as Forças Armadas não apenas foram afastadas da segurança interna, mas também se reorganizaram doutrinariamente para evitar que novamente pudessem ser empregadas em situações que deturpassem o seu papel constitucional, não obstante o próprio texto da Carta de 1988 ainda preservar a possibilidade do acionamento das Forças Armadas, dentro dos limites constitucionais, para excepcionalmente manter a lei e a ordem internas, notadamente na preservação da ordem pública e da incolumidade das pessoas e do patrimônio ${ }^{13}$, além de, sem prejuízo das competências exclusivas das polícias judiciárias, exercer atividades subsidiárias mediante cooperação em ações preventivas e repressivas, na faixa de fronteira terrestre, no mar e nas águas interiores contra delitos transfronteiriços e ambientais, isoladamente ou em coordenação com outros órgãos do Poder Executivo $^{14}$, mediante a distinção entre os conceitos de "segurança" e "defesa nacional" - esta, não mais exclusiva da área militar, mas gênero que a abrange -, na forma prevista na atual Política de Defesa Nacional ${ }^{15}$ :

1.4. Para efeito da Política de Defesa Nacional, são adotados os seguintes conceitos:

I - Segurança é a condição que permite ao País a preservação da soberania e da integridade territorial, a realização dos seus interesses nacionais, livre de pressões e ameaças de qualquer natureza, e a garantia aos cidadãos do exercício dos direitos e deveres constitucionais; II - Defesa Nacional é o conjunto de medidas e ações do Estado, com ênfase na expressão militar, para a defesa do território, da soberania e dos interesses nacionais contra ameaças preponderantemente externas, potenciais ou manifestas.

A Constituição de 1946 disciplinou que o estado de sítio teria cabimento nos casos de "guerra externa" e de "comoção intestina grave com o caráter de guerra civil", mantendo-se, em cada situação, a vigência de determinadas garantias constitucionais. Na mesma linha, prescreveu que a edição do estado de sítio também deveria especificar quando os crimes - mesmo que cometidos por civis - contra a "segurança da Nação ou das suas instituições políticas e sociais" estariam sob a competência da jurisdição e da legislação militares, definindo-se, também, as pessoas

\footnotetext{
${ }^{13}$ Art. 142, caput, da Constituição de 1988, e art. 15, caput, da Lei Complementar nº 97, de 09 de junho de 1999.

${ }^{14}$ Arts. $15, \S \S 2^{\circ}$ ao $7^{\circ}$, e 16-A da Lei Complementar no 97 , de 09 de junho de 1999.

${ }^{15}$ Decreto ${ }^{0}{ }^{5}$.484, de 30 de junho de 2005.
} 
responsáveis pela execução das medidas de exceção e as zonas ou localidades nas quais o instituto seria aplicado para efeito da jurisdição e legislação militares ${ }^{16}$.

Ainda quanto ao estado de sítio, o texto da Constituição de 1946 preservou a imunidade dos membros do Congresso Nacional durante a execução do instituto, ressalvando, por outro lado, a possibilidade de suspensão quando a liberdade de parlamentares fosse considerada incompatível com a "defesa da Nação ou com a segurança das instituições políticas ou sociais". Para tanto, seria necessário o voto de dois terços dos membros da Câmara dos Deputados ou do Senado Federal, conforme a origem do parlamentar, sendo possível, se em recesso, que a deliberação ocorresse ad referendum do Presidente da Câmara ou do Vice-Presidente do Senado, respectivamente, caso em que a convocação de cada Casa deveria ocorrer em quinze dias para votar a deliberação que fosse tomada ${ }^{17}$.

$\mathrm{Na}$ autoridade do Presidente da República estava concentrado o poder privativo de exercer o comando supremo das Forças Armadas, bem como de decretar sua mobilização total ou parcial, além, por via de consequência, de decretar o estado de sítio $^{18}$. O texto constitucional também permitiu ao Congresso Nacional editar o estado de sítio nos casos de "comoção intestina grave ou de fatos que evidenciem estar a mesma a irromper" e de "guerra externa"19, sendo que, quando no intervalo de sessões legislativas, o poder privativo do Presidente da República era ampliado: adquiria a natureza de poder exclusivo para decretar ou prorrogar o estado de sítio, condicionado à aprovação - ou não - do Congresso Nacional, este obrigatoriamente convocado pelo Presidente do Senado Federal para se reunir e deliberar no interregno de 15 dias $^{20}$.

Quando o estado de exceção fosse decretado pelo Congresso Nacional ao fundamento de "comoção intestina grave ou de fatos que evidenciem estar a mesma a irromper" ${ }^{\prime \prime}$, a regra geral somente permitia a suspensão de direitos fundamentais que obrigassem as pessoas a permanecer em determinada localidade, de realizar detenções em prédios diferentes aos dos destinados a réus comuns e de remoção de pessoas para outros locais no país, desde que povoados e salubres ${ }^{22}$,

\footnotetext{
${ }^{16}$ Art. 207, caput e parágrafo único, c/c art. 212 da Constituição de 1946.

${ }^{17}$ Art. 213, caput e parágrafo único da Constituição de 1946.

${ }^{18}$ Art. 87, incisos XI, XII e XIII da Constituição de 1946.

${ }^{19}$ Art. 206, incisos I e II da Constituição de 1946.

${ }^{20}$ Art. 208, parágrafo único da Constituição de 1946.

${ }^{21}$ Art. 206, inc. I da Constituição de 1946.

${ }^{22}$ Art. 209, incisos I a III da Constituição de 1946.
} 
isto é, com garantias mínimas de dignidade humana. Entretanto, na decretação do estado de sítio por ato exclusivo do Presidente da República, o instituto poderia alcançar as seguintes medidas, de caráter significativamente mais amplo ${ }^{23}$ : censura de correspondência ou de publicidade, inclusive a de radiodifusão, cinema e teatro; suspensão da liberdade de reunião, inclusive a exercida em associações; busca e apreensão em domicílio; suspensão do exercício do cargo ou função a funcionário público ou empregado de autarquia, de entidade de economia mista ou de empresa concessionária de serviço público; e intervenção nas empresas de serviços públicos.

É interessante destacar que a decretação do estado de sítio no caso de "comoção intestina grave ou de fatos que evidenciem estar a mesma a irromper"24, o prazo de vigência do instituto não poderia exceder a trinta dias ou mesmo ser prorrogado, salvo quando decretado pelo Presidente da República no intervalo das sessões legislativas do Congresso Nacional, circunstância em que o Poder Legislativo, quando reunido, poderia revogar, manter ou prorrogar a medida extrema ${ }^{25}$. No caso de guerra externa ${ }^{26}$, a vigência do estado de sítio corresponderia ao prazo de duração do conflito ${ }^{27}$.

Como medida de segurança jurídica e de garantia de direitos políticos, ao admitir a possibilidade de emenda à Constituição, o denominado constituinte de 1946 proibiu expressamente a reforma da Carta durante o estado de sítio $^{28}$. Essa previsão expressa é muito elucidativa quanto à natureza excepcional do instituto, na medida em que a sua existência se justificava pela necessidade de conter a exacerbação de poderes por parte daqueles que estivessem na liderança política e executiva das instituições incumbidas da execução das medidas excepcionais, notadamente aquelas que decorreriam da suspensão de direitos fundamentais. A concepção desse limite de poderes corresponde à imperiosidade de manter a vigência da Constituição, de respeitar seus princípios, seu sistema de direitos, suas garantias políticas, tendo em vista que a excepcionalidade do estado de sítio, que se caracteriza pela suspensão, pela exceção da plenitude da ordem constitucional, não pode dar lugar à substituição das instituições democráticas pelo fascínio ou o arbítrio de quem está investido ou colocado no exercício de um poder temporalmente

\footnotetext{
${ }^{23}$ Art. 209, parágrafo único, incisos I a V da Constituição de 1946.

${ }^{24}$ Art. 206, inc. I da Constituição de 1946.

${ }^{25}$ Art. 211 da Constituição de 1946.

${ }^{26}$ Art. 206, inc. II da Constituição de 1946.

${ }^{27}$ Art. 210 da Constituição de 1946.

${ }^{28}$ Art. $217, \S 5^{\circ}$ da Constituição de 1946.
} 
restrito para cumprir a teórica finalidade específica de restabelecer a ordem interna ou de fazer frente à defesa externa do país.

Nessa passagem pelos dispositivos selecionados da Constituição de 1946 é possível identificar que a democracia brasileira se desenvolvia ao tempo em que reforçava os instrumentos de preservação do Estado e, por via de consequência, da sociedade. Verifica-se que o regime democrático ainda encontrava-se vulnerável a ameaças ou ataques externos que exigissem a tradicional atuação dos meios militares, isto é, das Forças Armadas, para garantir a soberania e a independência nacionais. Contudo, as preocupações transcendiam a defesa marítima, territorial e do espaço aéreo e alcançavam as revoltas internas, as disputas, as comoções intestinas, fazendo com que a Carta Política estabelecesse o estado de sítio como medida extrema para o enfrentamento dessas situações. Veja-se a advertência de Aguiar $^{29}$ :

Com a edição da Carta de 1946, o Brasil estava pronto, em termos legais, para sofrer o crescimento vertiginoso das intervenções armadas, que desembocam na tomada do poder pelos próprios militares, que resolveram, eles mesmos, traduzir concretamente seus projetos, enfeixando nas mãos o aparelho de Estado. Tudo pela ordem, pela democracia, pela honestidade e pelo combate às forças anticristãs representadas pelos comunistas e seus aliados.

Embora, como visto, mesmo de natureza excepcional, o estado de sítio não suspendia amplamente a Constituição e ainda preservava o exercício da representação política e o funcionamento das instituições democráticas, limitando a aplicação do instituto a curto período de vigência (trinta dias). A transposição desses limites constitucionais foi uma questão de tempo, como veremos a seguir.

\section{A INSTALAÇÃO DO REGIME DE EXCEÇÃO: FUNDAMENTOS JURÍDICOS E POLÍTICOS}

As tensões internacionais decorrentes dos conflitos ideológicos entre direita e esquerda, entre liberalismo e comunismo recrudescem o cenário político brasileiro e, com a renúncia do Presidente Jânio da Silva Quadros em 21 de agosto de 1961, a rejeição que o Vice-Presidente João Belchior Marques Goulart (que se encontrava

${ }^{29}$ AGUIAR, Roberto Armando Ramos de. Os militares e a Constituinte: poder civil e poder militar na Constituição. São Paulo: Alfa-Ômega, 1986, p. 28. 
em viagem à China) teve dos militares para assumir a Presidência, Paschoal Ranieri Mazzilli, então Presidente da Câmara dos Deputados, assume a Presidência da República. Goulart ainda exerceria a Presidência durante o período de 08 de setembro de 1961 a 24 de janeiro de 1963, por força da Emenda Constitucional $\mathrm{n}^{\mathrm{o}}$ 4, de 22 de setembro de 1961, que instituiu o sistema parlamentar de governo. Mazzilli voltaria a assumir transitoriamente a Presidência, sob a forma de governo provisório e, em 15 de abril de 1964, entrega o cargo ao Marechal Humberto de Alencar Castelo Branco, momento em que se inicia o período da ditadura militar, marcado pelo primeiro governo do chamado Movimento Revolucionário instituído em 31 de março de 1964.

A ditadura iniciada em 1964 invocou as prerrogativas de poder constituinte originário, isto é, fundante, decorrente do que intitulou de Revolução Vitoriosa na qual estaria inserto o conceito de movimento civil e militar, investindo-se, por via de consequência, no Poder Constituinte a partir do qual a Constituição de 1946 seria gradativa e sistematicamente modificada para, ao final, ser substituída pela Carta de 1967 e, esta, revolvida pelos atos institucionais, pelos atos complementares e pelas emendas constitucionais que se sucederam até a redemocratização do Brasil e a promulgação da Carta de 1988.

A abordagem do presente trabalho está circunscrita apenas ao ato fundante do regime de exceção, ou do golpe militar ou da Revolução Vitoriosa de 1964: o Ato Institucional $\mathrm{n}^{\circ} 1$, de 09 de abril de 1964, que, dentre outras medidas, modificou a Constituição de 1946 quanto à eleição, ao mandato e aos poderes do Presidente da República, e conferiu aos Comandantes-em-chefe das Forças Armadas o poder de suspender direitos políticos e cassar mandatos legislativos, excluindo a prática desses atos da apreciação judicial. A parte preambular do Ato Institucional $n^{0} 1$, de 1964, foi permeado pelos argumentos jurídicos e políticos fundantes do regime de exceção que naquele momento era instalado. Com a finalidade de melhor compreender o novo desenho jurídico-político, será adotada a seguinte sistematização:

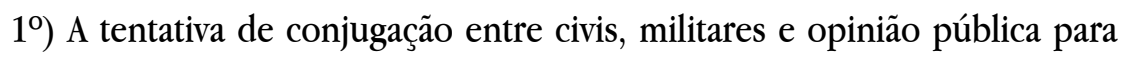
sustentar legitimidade à revolução:

É indispensável fixar o conceito do movimento civil e militar que acaba de abrir ao Brasil uma nova perspectiva sobre o seu futuro. $\mathrm{O}$ que houve e continuará a haver neste momento, não só no espírito e no comportamento das classes armadas, como na opinião pública nacional, é uma autêntica revolução. 
$2^{\circ}$ ) O esforço para demonstrar que o movimento representou consenso de toda a nação:

A revolução se distingue de outros movimentos armados pelo fato de que nela se traduz, não o interesse e a vontade de um grupo, mas o interesse e a vontade da Nação.

$3^{\circ}$ ) A conjugação entre o argumento da legitimação e o atendimento da vontade nacional autorizaria a tomada ou a investidura nas prerrogativas do poder constituinte, originário e fundante de uma nova ordem política e social, determinante de direitos e deveres:

A revolução vitoriosa se investe no exercício do Poder Constituinte. Este se manifesta pela eleição popular ou pela revolução. Esta é a forma mais expressiva e mais radical do Poder Constituinte. Assim, a revolução vitoriosa, como Poder Constituinte, se legitima por si mesma. Ela destitui o governo anterior e tem a capacidade de constituir o novo governo. Nela se contém a força normativa, inerente ao Poder Constituinte. Ela edita normas jurídicas sem que nisto seja limitada pela normatividade anterior à sua vitória. Os Chefes da revolução vitoriosa, graças à ação das Forças Armadas e ao apoio inequívoco da Nação, representam o Povo e em seu nome exercem o Poder Constituinte, de que o Povo é o único titular. O Ato Institucional que é hoje editado pelos Comandantes -em-Chefe do Exército, da Marinha e da Aeronáutica, em nome da revolução que se tornou vitoriosa com o apoio da Nação na sua quase totalidade, se destina a assegurar ao novo governo a ser instituído, os meios indispensáveis à obra de reconstrução econômica, financeira, política e moral do Brasil, de maneira a poder enfrentar, de modo direto e imediato, os graves e urgentes problemas de que depende a restauração da ordem interna e do prestígio internacional da nossa Pátria. A revolução vitoriosa necessita de se institucionalizar e se apressa pela sua institucionalização a limitar os plenos poderes de que efetivamente dispóe. (g. n.)

$4^{\circ}$ ) A assertiva de que a democracia foi insuficiente para formar consensos destinados a pacificar ou equilibrar os pensamentos políticos divergentes:

O presente Ato institucional só poderia ser editado pela revolução vitoriosa, representada pelos Comandos em Chefe das três Armas que respondem, no momento, pela realização dos objetivos revolucionários, cuja frustração estão decididas a impedir. Os processos constitucionais não funcionaram para destituir o governo, que deliberadamente se dispunha a bolchevizar o País. (g. n.) 
$5^{\circ}$ ) A suspensão do ordenamento jurídico vigente, quando incompatível com o exercício do regime de exceção, que passou a ter o poder de normatizar:

Destituído pela revolução, só a esta cabe ditar as normas e os processos de constituição do novo governo e atribuir-lhe os poderes ou os instrumentos jurídicos que lhe assegurem o exercício do Poder no exclusivo interesse do País. (g. n.)

$6^{\circ}$ ) A simbólica preservação da Carta de 1946 e a inequívoca opção liberal para o modelo de atuação governamental, restringindo-se poderes do Congresso Nacional:

Para demonstrar que não pretendemos radicalizar o processo revolucionário, decidimos manter a Constituição de 1946, limitandonos a modificá-la, apenas, na parte relativa aos poderes do Presidente da República, a fim de que este possa cumprir a missão de restaurar no Brasil a ordem econômica e financeira e tomar as urgentes medidas destinadas a drenar o bolsão comunista, cuja purulência já se havia infiltrado não só na cúpula do governo como nas suas dependências administrativas. Para reduzir ainda mais os plenos poderes de que se acha investida a revolução vitoriosa, resolvemos, igualmente, manter o Congresso Nacional, com as reservas relativas aos seus poderes, constantes do presente Ato Institucional. (g. n.)

$\left.7^{\circ}\right)$ A dispensabilidade do Congresso Nacional para conferir legitimidade ao movimento, isto é, a representação popular contida nos parlamentares é transferida diretamente aos dirigentes do governo, suprimindo-se, por conseguinte, os debates políticos. Na prática, a existência do Congresso passa a depender da ditadura:

Fica, assim, bem claro que a revolução não procura legitimar-se através do Congresso. Este é que recebe deste Ato Institucional, resultante do exercício do Poder Constituinte, inerente a todas as revoluções, a sua legitimação. (g. n.)

Em nome da revolução vitoriosa, e no intuito de consolidar a sua vitória, de maneira a assegurar a realização dos seus objetivos e garantir ao País um governo capaz de atender aos anseios do povo brasileiro, o Comando Supremo da Revolução, representado pelos Comandantes-em-Chefe do Exército, da Marinha e da Aeronáutica resolve editar o seguinte. [...]

O novo governo, sob o argumento de revolução que se coloca contra a subversão e a corrupção para assegurar os interesses nacionais se investe de 
plenos poderes políticos e jurídicos a partir dos quais uma nova ordem passa a ser implantada. O Ato Institucional $n^{\circ} 1$, que iniciou sua vigência em 09 de abril de 1964 e que deveria produzir efeitos somente até 31 de janeiro de $1966^{30}$, foi sucedido de outros dezesseis atos institucionais até o fim do regime militar, que durou de $1^{\circ}$ de abril de 1964 a 15 de março de 1985, isto é, por quase 21 anos.

A título de ilustração, destaca-se a secular ditadura dos romanos como medida excepcional para restabelecer a ordem na cidade antiga, Roma. Tratava-se de medida extrema que era, por natureza, transitória e episódica, justamente para não deturpar-se e contaminar o modelo republicano do Império. Por sua vez, o pretenso modelo de estabilização política adotado pelo Brasil não foi capaz de cumprir o propósito a que se propôs - se legitimado ou não -, notadamente em razão das tensões políticas e da duração, por duas décadas, do regime de exceção.

Neste momento revela-se pertinente trazer algumas abordagens teóricas de Schmitt ${ }^{31}$, que nos pareceram pertinentes para, de forma comparada, refletirmos a respeito do modelo de ditadura brasileiro adotado de 1964 a 1985. Schmitt organiza sua Teologia Política em duas abordagens nos anos de 1922 e 1970. Na primeira, o autor discorre a respeito de Quatro capítulos sobre a doutrina da soberania e, na segunda, sobre A legenda da resolução de toda Teologia Política, que compreendem os subtítulos da obra. Não é tarefa das mais fáceis analisar criticamente as questões suscitadas, muitas das quais atuais e controvertidas.

Em Teoria Política I, ao tratar da definição de soberania, Schmitt ${ }^{32}$, a partir dos estudos de Bodin, questiona "Até que ponto o soberano se submete às leis e se obriga diante das corporações?". Essa questão permeia todo o sentido da primeira parte da abordagem e funciona como pano de fundo daquilo que o soberano - ou quem exerce o poder de governar, de liderar - tem o dever de fazer para "manter a ordem e a segurança pública", o que remete a uma linha de atuação muito mais complexa que repercute direta e profundamente nos mecanismos do direito público: "quem decide sobre as competências constitucionais não regulamentadas, ou seja, quem é competente quando a ordem jurídica não oferece resposta à questão da competência"33.

Nesse ponto, é importante considerar que o estado de exceção estaria fora da ordem jurídica, do direito escrito, positivado, isto é, a excepcionalidade determinada por uma tal necessidade não encontraria previsão ou resposta nas normas jurídicas,

\footnotetext{
${ }^{30}$ Art. 11 do Ato Institucional no 1 , de 09 de abril de 1964.

${ }^{31}$ SCHMITT, Carl. Teologia política. Belo Horizonte: Del Rey, 2006.

32 SCHMITT, Carl. Teologia política. Belo Horizonte: Del Rey, 2006, p. 9.

33 SCHMITT, Carl. Teologia política. Belo Horizonte: Del Rey, 2006, p. 11.
} 
as quais funcionariam apenas para uma realidade convencional, sem anormalidades. O exercício da soberania - interna e externa - estaria potencializado. A anormalidade factual permitiria o exercício da soberania sob os contornos do direito (princípios) e da apropriação das normas jurídicas que, a partir de então, seriam aplicadas. Esse argumento abre espaço para iniciativas que podem chegar a ameaças totalitárias que se apropriariam do estado de direito para implementar ideologias dominantes, a partir do poder de decidir, ao que Schmitt ${ }^{34}$ deixa claro:

A exceção não é subsumível; ela se exclui da concepção geral, mas, ao mesmo tempo, revela um elemento formal jurídico específico, a decisão na sua absoluta nitidez. Em sua configuração absoluta, o estado de exceção surge, então, somente quando a situação deva ser criada e quando tem validade nos princípios jurídicos.

Essa ideia é reforçada quando Schmitt ${ }^{35}$ afirma que o "direito é situacional", cabendo ao soberano criar e garantir a situação de exceção mediante o exercício do "monopólio da decisão". Naturalmente, aqui estão afastados os pressupostos de estado de direito democrático na medida em que o soberano se coloca acima dos ordenamentos jurídicos para exercer o poder de decidir sobre o Estado e a sociedade. Portanto, há o problema da representatividade política e, consequentemente, da legitimidade. A representatividade política se perdeu quando da supremacia em que se fundamenta a exceção, a necessidade de decidir sobre algo que as normas jurídicas não previram ou não consideraram com pertencentes ao ordenamento jurídico. A legitimidade pode ser erigida com base em uma mensagem ideológica de salvação, de nacionalismo - que é justamente o excesso que se coloca incompatível com o cenário de normas jurídicas que, nos modelos democráticos, limita a atuação do Estado e dos representantes do poder soberano ou político. Veja-se a seguinte colocação de Schmitt $^{36}$ :

A exceção é mais interessante do que o caso normal. O que é normal nada prova, a exceção comprova tudo; ela não apenas confirma a regra, mas esta vive a exceção. Na exceção, a forma da vida real transpõe a crosta mecânica fixada na repetição.

$\mathrm{Na}$ especulação a respeito do problema da norma jurídica e da decisão, Schmitt ${ }^{37}$ aguça o debate a respeito da superação "formalista" para a solução de

\footnotetext{
${ }^{34}$ SCHMITT, Carl. Teologia política. Belo Horizonte: Del Rey, 2006, p. 13.

${ }^{35}$ Ibidem, 2006, p. 14.

${ }^{36}$ Ibidem, 2006, p. 15.

${ }^{37}$ Ibidem, 2006, p. 17.
} 
"problemas jurídico-estatais". O autor argumenta que situações práticas podem determinar a adoção de medidas que modifiquem "concepções tradicionais". Schmitt discute as construções teóricas de Bodin, Kelsen, Krabbe, Wolzendorff, Weber, Locke e Hobbes para formular seu ponto de vista a respeito da relação entre norma jurídica e decisão. Na prática sua linha de pensamento diz respeito à construção de legitimidade do poder soberano em constituir estado de exceção deslocado do ordenamento jurídico e, ao mesmo tempo - por mais paradoxal que possa parecer - vinculado (ou melhor, vinculando) as normas jurídicas. Tal construção unifica o poder do Estado ao poder da Constituição e ambos à prerrogativa de decidir do soberano, que não é mais a coletividade, o povo, ou suas instituições representativas, mas sim a pessoa física e política que se encontra investida, ou melhor, que se investiu do poder de tomar decisões no estado de exceção, o que se verifica da leitura das seguintes passagens:

Um sistema contínuo de ordens, partindo de uma última norma original suprema para uma inferior, ou seja, delegada, pode ser pensado dessa forma. $\mathrm{O}$ argumento decisivo, sempre, novamente, repetido e apresentado, exaustivamente, contra todo opositor científico, permanece o mesmo: o motivo para a validade de uma regra somente poder ser, por sua vez, uma norma; o Estado, portanto, para a análise jurídica, é idêntico à sua Constituição, ou seja, a norma fundamental uniforme/homogênea ${ }^{38}$.

O Estado limita-se, exclusivamente, à produção jurídica. Todavia isso não significa que ele produza Direito substancialmente. Ele nada faz a não ser constatar o valor jurídico de interesses como ele é produzido segundo a consciência jurídica dos cidadãos ${ }^{39}$.

A abordagem de $\operatorname{Schmitt}^{40}$ a respeito da decisão incorreta e de sua juridicidade suscita uma série de dúvidas, notadamente quanto à imputabilidade decorrente. Ao articular que "a decisão nasce do nada" e que à "decisão incorreta" (que seria ilegal ou inconstitucional) e à "decisão defeituosa" têm um dado "efeito jurídico" a partir do qual surge um ponto de inflexão que, por sua vez, "contém um momento constitutivo", decorrente da "inexatidão", demonstra que, no ponto em que se apropria para legitimar a decisão, o estado de exceção, estendendo-lhe, ainda, a imputabilidade, incorre na perigosa equação dentro-mas-fora das normas jurídicas.

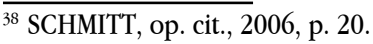

${ }^{39}$ Ibidem, 2006, p. 23.

${ }^{40}$ Ibidem, 2006, p. 30-33.
} 
Na parte final de Teologia Politica I, Schmitt ${ }^{41}$ deixa evidente que, no seu entender, o estado de exceção, ao ser justificado pela necessidade, transpõe a normatividade jurídica convencional para constituir o direito propriamente dito. $\mathrm{E}$ esse fenômeno seria tão profundo e significativo que utiliza em sua argumentação a combinação de conceitos de Estado e conceitos teológicos secularizados, destacando a transferência da teoria teológica para a teoria do Estado:

À medida que o Deus onipotente tornou-se o legislador onipotente,
mas, também, na sua estrutura sistemática, cujo conhecimento é ne-
cessário para uma análise sociológica desses conceitos. O Estado de
exceção tem um significado análogo para a jurisprudência, como o
milagre para a teologia ${ }^{42}$.

Schmitt ${ }^{43}$ faz a indicação de que o Estado de exceção possa ser revestido desse direito natural ${ }^{44}$, que foi abandonado à medida que a humanidade (ou considerável parcela dela), a partir do positivismo jurídico, assumiu a prerrogativa de estabelecer suas próprias regras de conduta, separando - ao menos no plano terreno das relações típica e socialmente humanas - o medo do desconhecido, do místico, do sobrenatural, tanto pelo Iluminismo quanto pela lei dos três estágios de Comte ${ }^{45}$.

Essas circunstâncias são muito importantes para compreender os modelos de organização estatal e jurídica, do passado e do presente, sob o ponto de vista da normatividade jurídica, que constitui fator determinante para o direito e, em especial, para o direito público conter abusos perpetrados em nome do Estado comandado por soberanos que exercem o poder de forma totalitária ou antidemocrática. Por outro lado, também permite que, em nome de ideologias nacionalistas e salvadoras, possa ser implementado o estado de exceção que, sob a invocação de um dado direito natural, colocaria seus líderes e executores imunes à imputabilidade de seus atos, de suas decisões.

Dessa breve abordagem do pensamento de Schmitt, a questão que fica para reflexão está contida nesse pêndulo que se movimenta entre teologia e Estado, entre religiões e normas jurídicas, das quais resultam exclusões e gradações entre pessoas

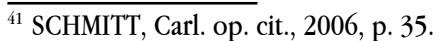

${ }^{42}$ Idem, p. 35.

${ }^{43}$ Idem, p. 35.

${ }^{44}$ Em futuras abordagens trataremos dessa questão utilizando o pensamento de Hans Kelsen (O problema da justiça. São Paulo: Martins Fontes, 1998).

${ }^{45}$ SCHMITT, Carl. op. cit., 2006, p. 80.
} 
e sociedades, entre decisões políticas e instrumentalização disfarçada ou explícita de noções de direito natural, que são incorporadas a ordenamentos jurídicos e que definem doutrinas e ideologias dominantes ou totalitárias.

Um dos críticos da teoria política schmittiana, Agamben ${ }^{46}$ questiona 0 mascaramento de um estado de exceção permanente, em especial nos estados ocidentais, notadamente depois da segunda guerra mundial, disfarçado por um aparente estado de normalidade democrática. O debate colocado pelo autor, lastreado intensamente na obra de Carl Schmitt, traz como pano de fundo o breu dos modelos fascista (Itália) e nazista (Alemanha) que formaram o ponto mais significativo de inflexão da teoria do direito no recente século XX e que repercute nos dias atuais: a posição das regras de exceção, se dentro ou fora dos sistemas jurídicos. Dessa posição resulta o sentido e o alcance da autoridade que exerce o poder político (e, por arrasto, do uso da violência, isto é, da força para estabelecer e impor condutas), a construção da legitimidade para a tomada de decisões (que repercutem nas sociedades nos planos interno e externo) e - mais duramente - a suspensão das regras jurídicas, substituídas por regras de exceção.

As incursões propostas por Agamben colocam em contradição política e normas jurídicas. E, claro, o que é feito com o direito, ao demonstrar a permanente tensão que caracteriza o uso das normas jurídicas pela política, para aplicação em modelos totalitários de organização e funcionamento de estados, de organização de sociedades. Se considerarmos o direito como o conjunto de mecanismos elaborados do humano para o humano - e então nos distanciando do direito natural, da representação de uma divindade, da metafísica - ao fundamento do qual as regras de conduta são elaboradas e aplicadas nas sociedades, por meio do poder organizador e coercitivo do Estado, a política não poderia simplesmente estabelecer e exigir determinado tipo de conduta. A política deveria traduzir as diversas demandas das sociedades e, a partir do direito, compor as soluções consensuais de justiça, nos campos do direito e da política. Naturalmente que essa função não alcança a utopia da harmonia social ou da inexistência de conflitos de interesse. Mas permitiria um espaço aberto à diversidade e à complementaridade que se ajustariam ao longo do processo histórico de cada sociedade.

$\mathrm{Na}$ percepção da Agamben $^{47}$, o poder político age ao mesmo tempo sob a perspectiva da ilusão e do apelo psicológico que coopta os desavisados, os

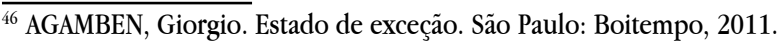

${ }^{47}$ Ibidem, 2011, p. 13.
} 
encantados e os servis ${ }^{48}$ adeptos que também se beneficiam dessa forma de exercício do poder. Instalado e exercido de forma totalitária ou absoluta, o autor traz à reflexão o apelo do estado de exceção, que não se extinguiu com o fim da segunda guerra mundial, mas que a partir desse conflito se transfigurou e estendeu suas teias até mesmo a modelos democráticos, fenômeno que chamou de "estado de emergência permanente" ${ }^{\prime 9}$. A emergência permanente para a proteção, a segurança de um estado de coisas alegadamente sob ameaça conduz os governos e as sociedade a um estado de militarização $0^{50}$.

Juntamente com Agamben ${ }^{51}$, vamos utilizar os estudos de Macedo $\mathrm{Jr}^{52}$ para compreender o pensamento de Carl Schmitt a fim de balizar as apropriações que possam ser aplicadas ao caso brasileiro. Macedo $\mathrm{Jr}^{53}$ investiga a fundamentação do direito em Schmitt destacando a originalidade e a profundidade do jurista alemão no período de 1922 a 1934, apesar das críticas que sua obra tem sofrido, principalmente quanto à conformação jurídica do modelo nazista na Alemanha. $\mathrm{O}$ autor assinala que Schmitt foi um representante do pensamento jurídico decisionista que se transformou sob a influência do pensamento jurídico institucionalista (das obras de Maurice Hauriou e Santi Romano), a partir de 1930.

Macedo Jr. ${ }^{54}$ assinala que Schmitt guarda coerência e compatibiliza o "pluralismo institucionalista" dos anos 1920, apesar das tensões conceituais que caracterizam o pensamento radical do jurista alemão. A partir de uma análise afastada e menos ideologizada, o autor realiza estudo de forma estruturada do pensamento de Schmitt, adotando uma metodologia histórica contextualizada e não dogmaticamente estrutural. Isso é muito importante, pois a percepção dos fatos históricos que formaram o pensamento jurídico e político é determinante para o entendimento das opções teóricas que adotou.

Em sua análise, Macedo Jr. ${ }^{55}$ demonstra que Schmitt, apesar de ser um intelectual militante, formulou preocupações científicas que vão além da perspectiva ideológica, autoritária ou totalitária que serviu ao III Reich, a Alemanha nazista.

\footnotetext{
${ }^{48}$ Nesse ponto poderemos aprofundar a abordagem mediante a reflexão a respeito da servidão voluntária descrita por Etienne de La Boètie (Discurso da servidão voluntária. São Paulo: Martin Claret, 2010).

${ }^{49}$ AGAMBEN, Giorgio. op. cit., 2011, p. 13.

${ }^{50}$ A esse respeito, o aprofundamento das reflexões terão espaço no pensamento de Paul Virilio (VIRILIO, Paul; SYLVERE, Lotringer. Guerra pura: a militarização do cotidiano. São Paulo: Brasiliense, 1984; Velocidade e política. São Paulo: Estação Liberdade, 1996; e Estratégia da decepção. São Paulo: Estação Liberdade, 2000).

${ }^{51}$ AGAMBEN, Giorgio. op. cit., 2011.

${ }^{52}$ MACEDO Jr., Ronaldo Porto. Carl Schmitt e a fundamentação do direito. São Paulo: Max Limonad, 2001.

${ }^{53}$ Ibidem, 2001, p. 13.

${ }^{54}$ Ibidem, 2001, p. 14.

${ }^{55}$ Ibidem, 2001, p. 15.
} 
Macedo Jr. ${ }^{56}$ considera Schmitt como um dos principais interlocutores do pensamento jurídico liberal, positivista e jusnaturalista da República de Weimar, polemizando com Kelsen, Locke e se aproximando de Hayek. O intrigante é que positivismo e jusnaturalismo, aparentemente antagônicos, convergem no pensamento de Schmitt para sustentar seus argumentos conservadores a respeito do poder de decidir do Estado - ou melhor, daquele que em nome do Estado toma decisões em uma determinada situação de necessidade, de anormalidade.

$\mathrm{Na}$ ponderação entre originalidade ou sistematização da obra de Schmitt, Macedo $\mathrm{Jr}^{57}$ destaca que o jurista alemão se dedicou a um projeto político com alternativas jurídicas que formulou para a República de Weimar, a compreender uma concepção de democracia e a crítica ao romantismo político. Valendo-se de George Schwab, o autor sintetiza o propósito de Schmitt: esboçar a linha constitucional para o projeto monopartidário nacional-socialista mediante o desenvolvimento do conceito de ordenamento concreto para a teoria do direito alemão.

Entretanto, Macedo $\mathrm{Jr}^{58}$ esclarece que a concepção do direito como pensamento do ordenamento concreto (1934) leva à concepção autoritária "fundada num princípio do Fübrer", a partir da qual Schmitt não entende o Fübrerprinzip como acepção estritamente decisionista, mas sim em uma concepção sincrética na qual o direito é um conjunto da instituição, norma e decisão que formam um ordenamento concreto. $\mathrm{O}$ autor assinala uma certa ingenuidade na pretensão de Schmitt como Kronjurist da Alemanha nazista ao dizer que o princípio do Fübrer estaria limitado pelas instituições e pelo povo, pois, na prática, o presidente não teria condições de manter o equilíbrio interno das instituições, tendo em vista que Adolf Hitler constituía perigo para a comunidade mundial e para as instituições alemãs, na medida em que a barbárie decisionista produzia violência e terror.

Para melhor compreender a obra de Schmitt, Macedo Jr. ${ }^{59}$ sistematizou o pensamento do jurista alemão em três tipos básicos, amadurecido a partir de 1934 (com a obra Sobre os três tipos do pensamento jurídico): 1) regra ou decisão; 2) ordenamento concreto; 3) configuração concreta. Antes, em 1920, Schmitt situava seu pensamento em dois tipos. Eis a sistematização:

\footnotetext{
${ }_{56}$ MACEDO Jr., op. cit., 2001, p. 16.

${ }^{57}$ Ibidem, 2001, p. 17.

${ }^{58}$ Ibidem, 2001, p. 18.

${ }^{59}$ Ibidem, 2001, p. 18-19.
} 


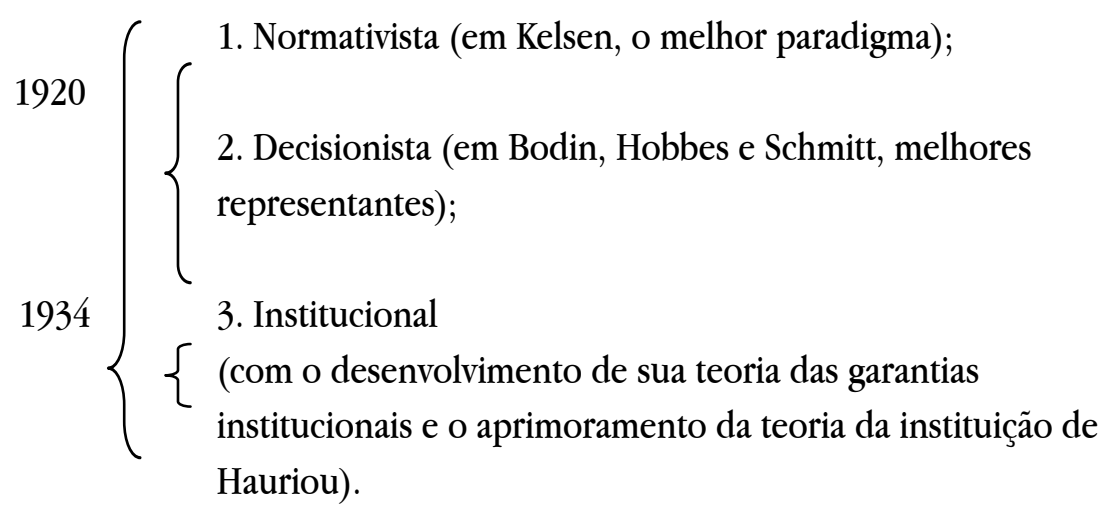

A análise realizada por Macedo $\mathrm{Jr}^{60}$ aborda os seguintes tópicos: cap. 1 - história e biografia de Schmitt; cap. 2 - o decisionismo e implicações com o ocasionalismo romântico; democracia ditatorial decisionista e sua afinidade com democracia totalitária (especialmente na crise de Weimar); cap. 3 - institucionalismo e implicações pluralistas; ordenamento concreto; e coerência interna de Schmitt; e cap. 4 - teoria sobre o novo direito internacional europeu (pós Segunda Guerra Mundial). Destaca-se ${ }^{61}$ o conceito de nomos que, "como law, não significa lei, regra ou norma, mas o direito, que é norma como decisão, bem como sobretudo ordenamento; e conceitos como rei, senhor, defensor ou governo, mas também juiz e tribunal, transportam-nos de imediato a ordenamentos institucionais concretos que não são mais meras regras". Traça-se, assim, uma correlação entre os conceitos de direito e soberania; direito como demarcação do campo jurídico; a determinação soberana do que é direito. Diferentemente, como indica Macedo Jr. ${ }^{62}$, Kelsen entende a soberania como fenômeno extrajurídico que não merece preocupação científica sobre o que é direito. Mas isso não afasta o interesse de Kelsen pelo aspecto político da soberania.

Conforme assinala Macedo $\mathrm{Jr}^{63}$, para Schmitt o nomos efetivo significa o conceito de direito total - e que vai sustentar as bases de um Estado (também) Total - que compreende ordenamento e comunidade concretos. Nessa linha de pensamento, soberano é quem decide na situação de exceção para instaurar ordem. É importante conhecer a relação entre ordenamento, normalidade (jurídica) e

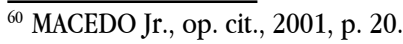

${ }^{61}$ Ibidem, 2001, p. 21.

${ }^{62}$ Ibidem, 2001, p. 21-22.

${ }^{63}$ Ibidem, 2001, p. 20.
} 
soberania e decisão.

Macedo Jr. ${ }^{64}$ traz os registros de que o pensamento de Schmitt recebeu influência do anti-positivismo neo-kantiano, sendo que o jurista alemão foi mesmo crítico do positivismo jurídico kelseniano. Em 1910 desenvolveu a ideia de finalidade moral do Estado que nada tinha em comum com o individualismo liberal. $\mathrm{O}$ direito produzido pelo Estado não poderia ter oposição, pois nele indivíduos não poderiam ter soberania. Schmitt acreditava que o Ocidente vivia o anti-individualismo.

$\mathrm{Na}$ narrativa histórica de Schmitt, Macedo $\mathrm{Jr}^{65}$ destaca que entre 1917 1920 ocorreu a Revolução Bolchevique e levantes comunistas alemães marcaram o debate político e ideológico. A burguesia receava a ruptura da ordem civil em razão da revolução. A exploração da propaganda nazista tinha como argumento os efeitos negativos do Tratado de Versailles com a perda de território da Alemanha para França. $\mathrm{O}$ advento da República de Weimar e a mudança do regime autoritário para o parlamentarismo influenciaram o pensamento de Schmitt. Esses fatos fazem com que Schmitt se distancie do romantismo político e passe a seguir o realismo de matriz conservadora.

Nesse ponto Macedo $\mathrm{Jr}^{66}{ }^{66}$ constata a obsessão de Schmitt pela possibilidade de crise e fragmentação do Estado alemão, considerando os seguintes fatos: crises políticas de Weimar, levantes revolucionários e os efeitos do Tratado de Versailles. Tais circunstâncias determinaram os argumentos de Schmitt a respeito do hamletismo político (incapacidade de o Estado decidir) e do uso dos poderes de exceção pelo governante, que formaram suas convicções a respeito do estado de necessidade como momento de exceção para o exercício do poder político, inclusive sobre o direito e a normatividade, na defesa do Estado alemão. Schmitt vivia o problema da indecisão que caracterizava o modelo parlamentarista liberal da Alemanha, onde o poder estava fragmentado em diversas instâncias políticas e sociais que influenciavam as escolhas políticas. Esse quadro desconstituía, na percepção de Schmitt, a história que marcava a origem prussiana do Estado Alemão, e que teria levado o país a severas perdas em decorrência da Primeira Guerra Mundial, em termos financeiros e territoriais.

Macedo Jr. ${ }^{67}$ registra que Schmitt não confiava em Adolf Hitler e na sua

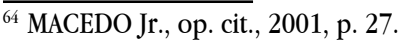

${ }^{65}$ Idem, p. 27.

${ }^{66}$ Idem, p. 27.

${ }^{67}$ Ibidem, 2001, p. 23.
} 
habilidade de liderar o processo de reformas para resgatar a capacidade de governar. No entanto, o jurista alemão tinha esperança na ditadura tradicional baseada na teoria dos ordenamentos concretos, o que poderia ocorrer com a ascensão de Hitler ao poder, oportunidade em que a teoria do Estado Total conservador poderia ser aplicada. Em 1932, Schmitt teria, inclusive, alertado a respeito dos perigos que poderiam advir com a ascensão de grupos radicais, como os nazistas e comunistas. O autor assinala a crença que Schmitt tinha de contribuir para uma espécie de refundação do Estado alemão, que poderia servir de base para a formação das bases políticas e jurídicas que pudessem marcar esse novo modelo autoritário de viés tradicionalista.

Contudo, em 1933 Schmitt filia-se ao partido nacional-socialista e se torna um dos juristas mais respeitáveis a aderir ao nazismo. No dizer de Macedo $\mathrm{Jr}^{6}{ }^{68}$, a filiação constituiu o pacto "mefistofélico com o Leviatã nazista, fundado na relação de obediência e proteção". Nesse modelo, Schmitt inicia uma série de publicações que sustentam que a forma de governo e a atuação do parlamento já não mais atendem aos anseios do povo alemão e que Hitler se tornou o Fübrer, de fato e de direito. Esses argumentos consolidam o cenário de necessidade que, por sua vez, sustentou o estado de exceção, fazendo com que o poder do Fübrer fosse a tal ponto ampliado, constituindo-o a um tempo decisão, fundamentação e criação de direito, formando um fenômeno político que preservava e não era atingido pelas regras de direito, mas que determinava sua interpretação e aplicação práticas com base na tomada de decisões sustentadas no argumento da preservação (ou do resgate) dos valores do Estado (original) alemão.

Macedo Jr. ${ }^{69}$ adverte para o fato de que a adesão de Schmitt ao nazismo, embora tenha inserido em seus argumentos "panfletários" as ideias de raça, sangue e identidade de estirpe, não aderiu à "teoria nazista oficial do racismo biológico", o que levou a sua exposição frente aos seus opositores que se encontravam inclusive no seio do regime nacional-socialista. Os que se opunham a Schmitt viam-no como um teórico oportunista. Note-se que Schmitt tinha esperança na ditadura tradicional baseada na teoria dos ordenamentos concretos para resgatar o que entendia ser a vitalidade, a origem do Estado alemão que, na sua visão, estava contaminado pelo modelo liberal que não tinha o Estado como único elemento de poder. Nesse ponto está revelada uma postura saudosista de Schmitt ao modelo prussiano e até mesmo

\footnotetext{
${ }^{68}$ MACEDO Jr., op. cit., 2001, p. 29.

${ }^{69}$ Ibidem, 2001, p. 30-31.
} 
romano-germânico que deu origem à Alemanha, pois, conforme mencionado anteriormente, ele acreditava na teoria do Estado Total conservador.

Para contornar as críticas que sofria, esclarece Macedo $\mathrm{Jr} \cdot{ }^{70}$ que Schmitt se esforçava em fundamentar a legitimidade de Hitler (esforço presente no texto $O$ Fübrer protege o direito), mas mesmo assim seus opositores ainda o consideram um oportunista e os ataques contra o jurista alemão foram intensificados. Schmitt tenta defender-se mediante adesão às Leis de Nuremberg, que tratavam da revogação dos direitos de cidadania dos judeus e da legalização do antissemitismo biológico-racial dos nazistas, onde raça deixa de ser um conceito ideológico para se transformar em categoria formal legal. É interessante observar que, a exemplo dos criminosos de guerra julgados no Tribunal de Nuremberg, Schmitt também adota o discurso de que apenas cumpria ordens superiores.

Macedo $\mathrm{Jr}^{71}{ }^{7}$ também destaca a dualidade de Schmitt reconhecida mesmo por Hannah Arendt, uma das principais estudiosas do totalitarismo. $\mathrm{O}$ jurista alemão chegou a ser considerado um pária no seio do regime nazista, cogitando-se, inclusive, sua emigração ou seu encaminhamento a campo de concentração. Schmitt, então, adota o silêncio a respeito de temas afetos à política interna alemã, fazendo com que acabassem as críticas ao seu nome. Conforme registra o autor, Schmitt vê frustrada a sua pretensão de influenciar a fundamentação do regime autoritário tradicional para a Alemanha.

O pensamento de Schmitt é caracterizado pelo decisionismo jurídico. Essa noção é a base de fundamentação do estado de exceção de sua teoria política. Macedo $\mathrm{Jr}^{72}$ identifica momentos desse pensamento que merecem destaque $\mathrm{e}^{73}: 1^{\mathrm{o}}$ ) o problema da decisão: a decisão judicial não está apenas na norma, pois haveria mesmo uma dada autonomia frente à norma que fundamentaria a legitimação da decisão fora do ordenamento jurídico e concentrado no exercício do poder político soberano; $2^{\circ}$ ) a teoria da ditadura e da soberania: a soberania caracterizada como decisão do estado de exceção e mecanismo de validade do ordenamento jurídico, isto é, decisão como comando que submete os ordenamentos jurídicos.

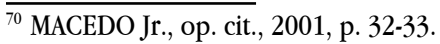

${ }^{71}$ Ibidem, 2001, p. 34-33.

${ }^{72}$ Ibidem, 2001, p. 39.

${ }^{73} \mathrm{Na}$ obra de 1912, Direito e Julgamento. Uma reflexão sobre o problema da práxis jurídica. Depois, A Ditadura (1921) e Teologia Política (1922).
} 
Ao tratar do decisionismo jurídico ${ }^{74}$ formulado por Schmitt, Macedo $\mathrm{Jr}^{75}$ destaca a crítica que o jurista alemão fez ao modelo liberal, que se encontrava limitado pela normatividade jurídica da legislação posta, isto é, do positivismo. Para Schmitt, o modelo liberal enfraquecia o Estado alemão e impedia o exercício do poder político em implementar mudanças. Uma vez que o poder se encontrava fragmentado (posto que dividido entre instituições e sociedade), era praticamente impossível, pela via normativa de normalidade, modificar o status quo. A não decisão do modelo parlamentar, liberal, era o estado de normalidade para o qual o ordenamento jurídico servia e a ele estava limitado.

A não decisão que inquietava Schmitt constituiu o ponto central de sua teoria para a ruptura do que para ele era um modelo de conformação. Logo, o caos que fundamenta o estado de exceção, por revelar uma necessidade tal de fixar um novo marco zero, constituía o ponto a partir do qual uma nova ordem política e jurídica seria constituída. Essa foi a ambição intelectual de Schmitt. Macedo $\mathrm{Jr}^{76}$ anota que esse momento também marca o distanciamento de Schmitt com o romantismo jurídico, de viés liberal, pois restaria incompatível manter o poder da soberania fragmentado nos indivíduos e mesmo na sociedade civil e nas instituições públicas. O poder político, para Schmitt, deveria ser concentrado, embora legitimado nos elementos Estado, Movimento e Povo. É o modelo da proteção com base na obediência.

Nessa ordem de ideias, segundo informa Macedo Jr. ${ }^{77}$, Schmitt constrói o argumento da democracia ditatorial decisionista. Os argumentos de Schmitt são dirigidos contra a fragmentação política do Estado contemporâneo determinada pelo pluralismo $^{78}$, pela policracia ${ }^{79}$ e pelo federalismo $0^{80}$. Diante desse quadro e mediante a associação dos argumentos de identidade e de representação, Schmitt sustentou que a democracia não era um modelo exclusivo do modelo liberal, mas que a democracia ditatorial decisionista representaria, na prática, a ligação entre o Estado (na figura do líder, do Führer) e o povo. E é exatamente essa ligação que levava a homogeneidade

\footnotetext{
${ }_{74}$ Considerando também o pensamento de Bodin e de Hobbes.

${ }^{75}$ MACEDO Jr., op cit., 2001, p. $42-46$.

${ }^{76}$ ibidem, 2001, p. 48-51.

${ }^{77}$ Ibidem 2001, p. 57-63.

78 "Multiplicidade de poderes sociais, estavelmente organizados que atravessam tanto o Estado como as unidades federadas (Länder) e territórios" (p. 63).

79 "Multiplicidade de titulares juridicamente autônomos da economia pública a cuja independência a vontade estatal encontra um limite" (p. 63).

80 "Proximidade e solidariedade de uma multiplicidade de Estados; pluralidade de formações estatais" (p. 63).
} 
entre o povo - leia-se ausência de divergência, de contradições, de dissenções, de opiniões contrárias, de discussão - e desta à identidade entre o povo e o Führer. Desse modo, como assinala o autor, a democracia "é um conceito independente e autônomo que pode ser combinado com o parlamentarismo, presidencialismo e até mesmo a ditadura de massas" ${ }^{\prime 1}$.

Na visão de Schmitt, como observa Macedo Jr. ${ }^{82}$, o Estado contemporâneo não mais poderia ser dominado pela economia liberal. Era preciso restringir a liberdade de mercado e proporcionar ao Estado uma capacidade ampla de intervir da economia. Para o jurista alemão, o modelo liberal clássico estava esgotado e não mais atendia às necessidades de preservação do Estado e de atendimento das necessidades do povo, fortalecendo a sua crença de que política (ditadura democrática) e juridicamente seria possível solucionar esses problemas ${ }^{83}$. Ainda mais: Schmitt defendia a quebra do modelo liberal de tripartição de poderes, sustentando que o Estado não poderia ser fragmentado por poderes contrapostos que se equilibrariam ${ }^{84}$. Schmitt ainda teria uma posição mais aguda: nem mesmo o poder Judiciário, na conformação apolítica, poderia decidir questões constitucionais de natureza política ${ }^{85}$.

Macedo Jr. ${ }^{86}$ destaca que Schmitt acabou por se convencer da importância das instituições para o modelo de organização política do Estado. Nessa linha, estabeleceu os três tipos de pensamento jurídico, inspirado na teoria institucionalista de Hauriou: norma, decisão e ordenamento (como instituição). Mas, como explica o autor ${ }^{87}$, Schmitt reconhecia por instituição aquela surgida pelo Estado, a partir da decisão do soberano (do estado de exceção, da necessidade) que instaurou a normalidade que surgiu do "nada", isto é, da ruptura que refunda o Estado, que decidiu o caos. Então, a instituição é nova e aderente ao novo modelo de organização política e jurídica ${ }^{88}$.

Ao final, Macedo $\mathrm{Jr}^{89}$ fixa o pensamento de Schmitt em quatro pontos essenciais: $1^{\circ}$ ) pensamento do ordenamento concreto é forma de decisionismo

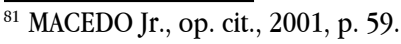

${ }^{82}$ Ibidem, 2001, p. 63.

${ }^{83}$ Ibidem, 2001, p. 66.

${ }^{84}$ Ibidem, 2001, p. 66.

${ }^{85}$ Ibidem, 2001, p. 67.

${ }^{86}$ Ibidem, 2001, p. 82.

${ }^{87}$ Ibidem, 2001, p. 112.

${ }^{88}$ Ibidem, 2001, p. 126.

${ }^{89}$ Ibidem, 2001, p. 133-142.
} 
institucionalista; $2^{\circ}$ ) o jurista alemão é um pensador católico conservador voltado às instituições tradicionais alemãs, o que afastaria a pecha de formulador do pensamento nazista; $3^{\circ}$ ) a formulação do decisionismo institucionalista contribuiu - mas não foi fundamental ou exclusivamente decisivo - para o Estado Totalitário alemão; e $4^{\circ}$ ) a reação contra o direito como produto de decisão de grupos políticos de "amigos e inimigos", que colocam em risco os interesses do Estado e da sociedade. As últimas contribuições teóricas ${ }^{90}$ de Schmitt indicam, como esclarece Macedo Jr. ${ }^{91}$, sua preocupação com o equilíbrio político mundial, em que o jurista alemão passa a abordar o direito pela perspectiva das relações sociais e econômicas, considerando o ordenamento social global.

O estudo da obra de Schmitt contribui para a análise dos modelos de organização política dos Estados contemporâneos, principalmente como o poder político pode se apropriar de ordenamentos jurídicos e instrumentalizar o próprio direito, sob o argumento da segurança (proteção) que oferece aos membros de uma dada sociedade, a fim de receber em troca o cumprimento das regras de conduta (obediência). Os cenários traçados por Schmitt contribuem para a compreensão de opções democráticas tanto liberais quanto socialistas, e do considerável potencial para práticas totalitárias, estejam disfarçadas ou explícitas.

Há várias diferenças entre a teoria schmittiana e o que podemos chamar de decisionismo presente no regime de exceção militar praticado no país em 1964. Entretanto, se o movimento que eclodiu na Alemanha nazista pretendia afastar a inércia do modelo liberal presente no sistema parlamentar que, utilizando as normas democráticas do estado de direito, não conseguia, na visão de Schmitt, resgatar os valores e a economia alemãs; no Brasil o decisionismo em que se fundamentou o argumento do regime de exceção objetivou frear, conter e reprimir a tentativa de mudança do modelo de liberalismo para socialismo ou, no limite, para o comunismo. Numa ou noutra experiência histórica, identifica-se a apropriação do argumento democrático e do interesse nacional para construir uma dada legitimidade que garantisse a concentração de poderes para fazer face à arquitetura principiológica dominante, tornando o ordenamento jurídico vigente, inclusive o de natureza constitucional, ora suspenso ora tangenciado, ora inaplicável aos comandos ordenados do vértice à base. Esse fenômeno precisa ser analisado para que possamos compreender as divergências que, na atualidade, constituem o ponto

\footnotetext{
${ }^{90}$ A exemplo de O Nomos da Terra (1950).

${ }^{91}$ MACEDO Jr., op. cit., 2001, p. 141.
} 
central do debate a respeito da aplicação da justiça de transição no Brasil, em face não apenas da Lei de Anistia ${ }^{92}$.

É possível reconhecer, nos fundamentos políticos do regime de exceção instalado em 1964 no Brasil, traços do argumento decisionista presente na teoria schmittiana, na medida em que o poder foi manejado para interferir no processo histórico de escolhas políticas que se opunham nos planos interno e externo, observado o modelo de organização política, então praticado, imerso em ambiente de tensões onde a excepcionalidade do uso da força e da suspensão de direitos políticos e fundamentais funcionou como ponto de inflexão e de adaptação da arquitetura normativa que, por sua vez, possibilitou a constitucionalidade e a legalidade de atos praticados pelo Estado e seus agentes, os quais, ainda nos dias de hoje, constituem pontos de divergências ideológicas e jurídicas no contexto da justiça de transição, na sua variante de responsabilização pela prática de crimes conexos aos crimes políticos.

A abordagem da teoria de Schmitt interessa ao presente trabalho apenas na medida em que contribui para o melhor entendimento do modelo decisionista e de como o exercício do poder é capaz de construir soluções jurídicas que, com contornos de legalidade e legitimidade, podem afastar mecanismos de responsabilização no curso da história.

\section{O REGIME DE EXCEÇÃO E A CARTA DE 1967}

Vinte e um anos depois da promulgação da Constituição de 1946 o Brasil passa a ter uma nova Carta, a de 24 de janeiro de $1967^{93}$. O texto constitucional mantem as linhas gerais da Constituição de 1946 e passa a intensificar o conjunto de mecanismos destinados a preservar o modelo de organização política, econômica e social. A preocupação com a segurança interna, com a subversão da ordem estabelecida e com a corrupção, constitui o principal ponto de inovação para fundamentar o tratamento especial que se fez presente no conjunto de dispositivos que insculpiram a noção e os procedimentos da chamada "segurança nacional", mas

\footnotetext{
${ }^{92}$ Lei $\mathrm{n}^{\circ} 6.683$, de 28 de agosto de 1979.

${ }^{93}$ Em vigor em 15 de março de 1967, quando Humberto de Alencar Castello Branco foi o Presidente da República no período de 15 de abril de 1964 a 15 março de 1967, sucedido por Arthur da Costa e Silva, que esteve no poder de 15 de março de 1967 a 31 de agosto de 1969.
} 
ainda insuficientes para o rigor do regime de exceção que estava por ser estabelecido em 1969.

A Constituição de 1967 permitia a organização de partidos políticos, que funcionassem e até mesmo fossem extintos, desde que mediante a observância, entre outros, do princípio representativo e democrático, ao fundamento da pluralidade e nas garantias de direitos fundamentais ${ }^{94}$, como também assegurava a brasileiros e estrangeiros residentes no Brasil a inviolabilidade do direito à vida, à liberdade, à segurança e à propriedade, sem distinções ou preconceito, prestigiando a liberdade das convicções filosóficas e políticas, mantendo o Poder Judiciário livre para apreciar lesão a direitos individuais ${ }^{95}$.

O texto do $\S 8^{\circ}$ do art. 150 da Constituição de 1967 manteve o acréscimo introduzido na parte final do então $\S 5^{\circ}$ do art. 141 da Carta de 1946, que prescreveu a intolerância à propaganda de guerra, de subversão da ordem ou de preconceitos de raça ou de classe ${ }^{96}$. A liberdade de trabalho, ofício ou profissão esteve prevista, assim como a possibilidade de reuniões pacíficas, sem armas, não havendo óbices à liberdade de associação, que somente poderia ser dissolvida por decisão judicial ${ }^{97}$. Entretanto, o abuso desses e dos direitos políticos, quando atentassem contra a ordem democrática ou se destinassem a atos de corrupção, implicaria a suspensão dos direitos políticos pelo período de dois a dez anos, por representação do Procurador-Geral da República, cabendo ao Supremo Tribunal Federal o ato declaratório correspondente ${ }^{98}$. Também nesse contexto, no campo da liberdade de pensamento e de informação, o texto constitucional permitiu que a legislação infraconstitucional definisse condições para a organização e o funcionamento de empresas jornalísticas, de televisão ou de radiodifusão, desde que no interesse do regime democrático e do combate à subversão e à corrupção $0^{99}$.

O conjunto de dispositivos constitucionais até então destacados compôs a construção do pano de fundo para a nova abordagem a respeito do estado de sítio e dos mecanismos de sua aplicação. Enquanto que a Constituição de 1946 prescrevia que o instituto seria aplicado nos casos de "comoção intestina grave ou de fatos

\footnotetext{
${ }_{94}$ Art. 149, inciso I da Constituição de 1967.

${ }^{95}$ Art. $150, \S \S 1^{\circ}, 4^{\circ}, 5^{\circ}, 6^{\circ}$ e $8^{\circ}$ da Constituição de 1967.

${ }^{96}$ Redação dada pelo Ato Institucional no 2, de 27 de outubro de 1965.

${ }^{97}$ Art. 150, §§ 23, 27 e 28 da Constituição de 1967.

${ }^{98}$ Art. 151 da Constituição de 1967.

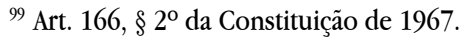


que evidenciem estar a mesma a irromper" e de "guerra externa"100, a Constituição de 1967 adotou novas terminologias: "grave perturbação da ordem ou ameaça de sua irrupção" e a "guerra"101. Note-se que essa reformulação de expressões ampliou a abrangência do estado de sítio para alinhá-lo à sistemática de proteção que se pretendia implantar, isto é, de combate à subversão da ordem vigente e de uma guerra que, pelo texto constitucional, não seria exclusivamente externa, ou seja, tangenciando o tradicional conceito de conflito armado para defender o país de ameaças efetivas ou potenciais advindas do exterior ${ }^{102}$.

Interessante conjugar essa noção de guerra com a inovação introduzida no sistema de direitos e garantias individuais, quando o texto constitucional, mesmo ao assegurar a inviolabilidade do direito à vida, à liberdade, à segurança e à propriedade, declarando a igualdade de todos perante a lei (igualdade formal), inclusive quanto às convicções políticas ${ }^{103}$, foi modificado ${ }^{104}$ para ressalvar que os casos de "guerra externa psicológica adversa, ou revolucionária ou subversiva” estariam afastados da vedação de pena de morte, de prisão perpétua, de banimento e de confisco ${ }^{105}$. Desse modo, a noção de conflito, ou de guerra, deixava de ser exclusivamente externa, para admitir, no limite, a variação revolucionária ou subversiva e, por conseguinte, interna, intestina, contra inimigos internos.

$\mathrm{Na}$ Constituição de 1967 , as medidas coercitivas do estado de sítio foram ampliadas para permitir a busca e a apreensão em domicílio, o uso ou a ocupação temporária de bens das autarquias, empresas públicas, sociedades de economia mista ou concessionárias de serviços públicos, além de conferir ao Presidente da República, ouvido o Conselho de Segurança Nacional, outras medidas estabelecidas em lei, sob o argumento da preservação da integridade e da independência nacionais, do livre funcionamento dos poderes e da "prática das instituições", quando sob ameaça de subversão ou corrupção ${ }^{106}$. O prazo de vigência do estado de sítio também foi ampliado de trinta para sessenta dias, admitida a prorrogação para o caso de grave

\footnotetext{
${ }^{100}$ Art. 206, incisos I e II da Constituição de 1946.

${ }^{101}$ Art. 152, incisos I e II da Constituição de 1967.

${ }^{102}$ Conforme preceituava a Constituição de 1967: Art. $7^{\circ}$. Os conflitos internacionais deverão ser resolvidos por negociações diretas, arbitragem e outros meios pacíficos, com a cooperação dos organismos internacionais de que o Brasil participe. Parágrafo único. É vedada a guerra de conquista. Art. 83. Compete privativamente ao Presidente: IX - declarar guerra, depois de autorizado pelo Congresso Nacional, ou sem esta autorização, no caso de agressão estrangeira verificada no intervalo das sessões legislativas.

${ }^{103}$ Art. 150 , caput e $\S 1^{\circ}$ da Constituição de 1967.

${ }^{104} \mathrm{Na}$ forma do Ato Institucional $\mathrm{n}^{\mathrm{o}} 14$, de 05 de setembro de 1969.

${ }^{105}$ Art. 150, $\$ 11$ da Constituição de 1967.

${ }^{106}$ Art. 152, § 20, alíneas "c" e "f", e $\S 3^{\circ}$ da Constituição de 1967.
} 
perturbação da ordem ou ameaça de sua irrupção $0^{107}$. Embora ampliadas as medidas do estado de sítio, o texto constitucional ainda permitia o acesso ao Poder Judiciário contra práticas coercitivas que não estivessem amparadas pelas normas vigentes, isto é, a exacerbação do poder de polícia ainda era considerada ilega ${ }^{108}$.

A segurança nacional é, portanto, elevada a tal ponto que a Constituição de 1967 atribuiu a toda pessoa natural ou jurídica a responsabilidade para o enfrentamento do tema, fazendo com que a prontidão e a vigilância permanentes mobilizassem o funcionamento não apenas do Estado e de suas instituições, mas também de cada indivíduo e toda a sociedade ${ }^{109}$. Diante desse fato, podemos dizer que o conjunto de valores e argumentos que foram movimentados estão associados ao problema da soberania, que carrega consigo o princípio da sobrevivência, do não-perdimento do Estado, da preocupação constante em manter o status quo. Por conseguinte, o esforço empregado para tal empreendimento não prescinde do direito, das regras jurídicas. Essa dependência proporciona a um tempo legitimidade e exclusão de ilicitude. Nesse contexto, as reflexões de Foucault ${ }^{110}$ :

[...] A teoria do direito, da Idade Média em diante, tem essencialmente o papel de fixar a legitimidade do poder; isto é, o problema maior em torno do qual se organiza toda a teoria do direito é o da soberania.

Afirmar que a soberania é o problema central do direito nas sociedades ocidentais implica, no fundo, dizer que o discurso e a técnica do direito tiveram basicamente a função de dissolver o fato da dominação dentro do poder para, em seu lugar, fazer aparecer duas coisas: por um lado, os direitos legítimos da soberania e, por outro, a obrigação legal da obediência. O sistema de direito é inteiramente centrado no rei e é, portanto, a eliminação da dominação e de suas consequências.

Nesse cenário, o Conselho de Segurança Nacional funcionava como órgão de assessoramento do Presidente da República e destinava-se à formulação e à conduta da segurança nacional, sendo composto pelo Presidente, pelo Vice-Presidente da República e pelos ministros de Estado ${ }^{111}$. As áreas de competência do Conselho passaram a ter previsão constitucional, dentro dos contornos da sistemática da Carta

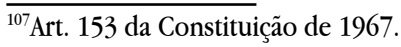

${ }^{108}$ Art. 156 da Constituição de 1967.

${ }^{109}$ Art. 89 da Constituição de 1967.

${ }^{110}$ FOUCAULT, Michel. Microfísica da poder. Rio de Janeiro: Graal, 1979, p. 181.

${ }^{111}$ Art. $90, \S 1^{\circ}$ da Constituição de 1967.
} 
de $1967^{112}$.

Notadamente quanto às Forças Armadas, a Constituição de 1967 preservouas como instituições nacionais permanentes - e agora também "regulares", isto é, seus integrantes não mais poderiam invocar um agir isolado, mas somente admitindo-se uma atuação integrada, institucionalizada, evitando-se insurreições nas corporações ${ }^{113}$ - ao fundamento da hierarquia e da disciplina, sob a autoridade suprema do Presidente da República para defender a pátria, garantir os poderes constituídos, a lei e a ordem ${ }^{114}$.

As Forças Armadas foram associadas à segurança nacional pois sua competência constitucional não mais estava limitada à defesa externa do país. A garantia dos poderes constituídos e, em especial, da lei e da ordem, colocava - como de fato ainda coloca, mesmo que de forma atenuada e limitada no texto da Carta de $1988^{115}$ e na Lei Complementar $n^{\circ} 97$, de 09 de junho de $1999^{116}$, e na legislação especial $^{117}$ - as instituições militares projetadas para a segurança interna do Estado e da sociedade, contra as ameaças que se caracterizavam por grave perturbação da ordem ou ameaça de sua irrupção.

Observa-se, nesse contexto, a competência da União para organizar as Forças Armadas, planejar e garantir a segurança nacional ${ }^{118}$. A polícia federal seguia semelhante linha, cabendo-lhe, entre outras tarefas, a apuração de infrações penais contra a segurança nacional, a ordem política e social ${ }^{119}$.

No campo político, embora preservada a autonomia municipal, a nomeação de prefeitos de municípios, feita pelos governadores, exigia a prévia aprovação do Presidente da República, em caráter privativo, para os municípios declarados por lei

\footnotetext{
${ }^{112} \mathrm{Na}$ Constituição de 1946 as competências do Conselho de Segurança Nacional foram remetidas a legislação infraconstitucional. Por sua vez, o texto da Carta de 1967 prescreveu: Art. 91. Compete ao Conselho de Segurança Nacional: I - o estudo dos problemas relativos à segurança nacional, com a cooperação dos órgãos de Informação e dos incumbidos de preparar a mobilização nacional e as operações militares; II - nas áreas indispensáveis à segurança nacional, dar assentimento prévio para: a) concessão de terras, abertura de vias de transporte e instalação de meios de comunicação; b) construção de pontes e estradas internacionais e campos de pouso; c) estabelecimento ou exploração de indústrias que interessem à segurança nacional; III - modificar ou cassar as concessões ou autorizações referidas no item anterior. Parágrafo único. A lei especificará as áreas indispensáveis à segurança nacional, regulará sua utilização e assegurará, nas indústrias nelas situadas, predominância de capitais e trabalhadores brasileiros.

${ }^{113}$ A exemplo do Movimento Tenentista (1922-1924).

${ }^{114}$ Art. 92, $\S 1^{\circ}$ da Constituição de 1967.

${ }^{115}$ Art. 142 da Constituição de 1988.

${ }^{116}$ Dispõe sobre a organização, o preparo e o emprego das Forças Armadas, e dá outras providências.

${ }^{117}$ Decreto $\mathrm{n}^{0} 3.897$, de 24 de agosto de 2001.

${ }^{118}$ Art. $8^{\circ}$, inciso IV da Constituição de 1967.

${ }^{119}$ Art. $8^{\circ}$, inciso VII, alínea "c" da Constituição de 1967.
} 
federal como de interesse da defesa nacional ${ }^{120}$.

$\mathrm{O}$ apelo à segurança nacional ganhou tamanha conformação jurídica a ponto de o texto constitucional permitir que o Presidente da República, ao argumento de urgência ou de interesse público relevante, sem aumento de despesa (o que seria irrelevante) editasse decretos com força de lei ${ }^{121}$ para também tratar de matéria afeta à segurança nacional ${ }^{122}$.

No esforço de manter a aparência democrática em que se fundam os princípios do devido processo legal e de acesso ao Judiciário, o texto da Constituição de 1967 não apenas seguiu o previsto na Carta de $1946^{123}$, mas foi significativamente modificado e ampliado para transferir ao foro especial da Justiça Militar o processo e o julgamento de civis (inclusive políticos: governadores e secretários de Estado) por crimes praticados contra a segurança nacional ou contra as instituições militares ${ }^{124}$. Note-se que a Constituição de 1946 tratava de crimes contra a "segurança externa" a defesa nacional tradicional, de conflito armado efetivo ou potencial - enquanto que a de 1967 passou a considerar simplesmente crimes contra a "segurança nacional" - as ameaças internas caracterizadas por grave perturbação da ordem ou ameaça de sua irrupção.

Durante o regime de exceção, a Constituição de 1967, sem a participação do Congresso Nacional, foi emendada vinte e uma vezes, recebeu cento e quatro atos complementares e dezessete atos institucionais ${ }^{125}$. Em especial, seu texto também sofreu as modificações introduzidas pela Emenda Constitucional $\mathrm{n}^{\mathrm{o}} 1$, de 17 de outubro de 1969, que, subscrita pelos ministros da Marinha de Guerra, do Exército e da Aeronáutica Militar, editou o novo texto da própria Carta de 1967. O ato, praticado pelas autoridades militares, deu-se ao fundamento da vacância dos cargos de Presidente e de Vice-Presidente da República, pois o então Presidente Marechal Arthur da Costa e Silva foi declarado como acometido de doença grave que lhe impedia de reassumir a plenitude das funções, além da previsão de que,

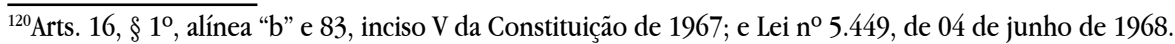

${ }^{121} \mathrm{Na}$ Constituição de 1988, a edição de medida provisória, que tem força de lei, não alcança matérias que digam respeito à segurança nacional ou à defesa nacional, sendo, inclusive, vedada a sua aplicação, dentre outros, em temas afetos a direitos políticos, partidos políticos, direito penal, direito processual penal, direito processual civil, detenção ou sequestro de bens (nos termos do art. $62, \S 1^{\circ}$, inciso I, alíneas "a" e "b", e inciso II).

${ }^{122}$ Art. 58, inciso I e parágrafo único da Constituição de 1967.

${ }^{123}$ Art. 108, caput e $\S 1^{\circ}$ da Constituição de 1946, modificado pelo Ato Institucional $n^{\circ} 2$, de 27 de outubro de 1965.

${ }^{124}$ Art. 122 , caput e $\$ \S 1^{\circ}$ e $2^{\circ}$ da Constituição de 1967 , modificado pelo Ato Institucional $n^{\circ} 6$, de $1^{\circ}$ de fevereiro de 1969.

${ }^{125}$ Em razão da delimitação temática, o exame detalhado dessas normas será objeto de estudos posteriores ao presente artigo.
} 
na impossibilidade de realizar eleições, a Chefia do Poder Executivo continuaria a ser exercida pelos Ministros militares ${ }^{126}$, considerado o recesso do Congresso Nacional ${ }^{127}$, cujo cenário de conformação jurídica permitiu que o governo militar assumisse a prerrogativa do processo legislativo ${ }^{128}$ que lhe autorizava a emendar o texto constitucional.

Podemos aqui ilustrar com o ensinamento de Bobbio $^{129}$ a respeito da ditatura revolucionária:

Uma das tarefas que Buonarroti atribui ao governo revolucionário dos "sábios" consiste em preparar a nova constituição que deverá concluir a fase revolucionária, mostrando, deste modo, para além de qualquer dúvida, que a característica saliente da ditadura revolucionária é o exercício do poder soberano por excelência que é o poder constituinte. Resta sublinhar que, não diversamente do uso clássico do termo, também no novo contexto "ditadura", embora tendo alterado o seu significado descritivo, não perdeu nada da originária conotação positiva com respeito ao significado valorativo. À diferença do uso hodierno, no qual "ditadura" enquanto contraposta a "democracia" assumiu, como já pude observar, uma conotação quase sempre negativa, o primeiro uso de "ditadura" para designar a ditadura revolucionária (e de resto também a ditadura militar) ressente-se do favor de que gozou o magistrado romano chamado em situações excepcionais para salvar a república de guerra ou rebeliões, e o termo acabou por ainda ser usado com uma conotação geralmente positiva.

Desse modo, o novo texto da Constituição de 1967, mesmo com a preservação de parte do texto original de 24 de janeiro de 1967, foi editado com a autorização dada ao Poder Executivo para legislar, fundando-se, por conseguinte, uma nova ordem constitucional com poderes sem precedentes, posto que o regime de exceção não havia suspendido a integralidade da Constituição ou afastado a produção dos efeitos, mas sim foi gradativamente inserido na própria ordem constitucional e infraconstitucional, fazendo com que o estado de sítio desse lugar ao estado de exceção. É a partir do estudo desse fenômeno jurídico que a gênese da justiça de transição poderá ser melhor compreendida, posto que ultrapassa a Lei de

\footnotetext{
$\overline{{ }^{126} \text { Preâmbulo e art. } 3^{\circ}}$ do Ato Institucional n ${ }^{\mathrm{o}} 16$, de 14 de outubro de 1969.

${ }^{127}$ Art. $2^{\circ}, \S 1^{\circ}$ do Ato Institucional $n^{\circ} 16$, de 14 de outubro de 1969 , e o Ato Complementar $n^{\circ} 38$, de 13 de dezembro de 1968, que decretou o recesso do Congresso Nacional.

${ }^{128}$ Art. 49, I da Constituição de 1967.

${ }^{129}$ BOBBIO, Norberto. Estado, governo e sociedade: por uma teoria geral da política. São Paulo: Paz e Terra, 2007, p. 164.
} 
Anistia e sua compatibilidade ou não com a Constituição de $1988^{130}$.

\section{CONSIDERAÇÕES FINAIS}

Olhar os fatos que marcaram as transformações políticas e jurídicas vivenciadas no Brasil desde 1946 constitui tarefa das mais interessantes e enriquecedoras, pois a cada análise textual e normativa novas lições são apreendidas. De forma bastante simples e carente de complementação, o presente artigo pretendeu percorrer o conjunto normativo em que se fundamentou a implantação do regime de exceção no Brasil a partir de 1964. Muito se fala, na atualidade, na revisão da Lei de Anistia e na punição de responsáveis por atos de tortura. Essa discussão é válida na democracia. $\mathrm{O}$ amadurecimento desse debate não prescinde da identificação e análise dos argumentos e valores que determinaram a construção da legitimidade, a assunção do poder constituinte e a alegada exclusão de ilicitudes por atos praticados. Portanto, a modesta pretensão deste trabalho não é outra senão a de reunir elementos que, somados a outros, possam esboçar a discussão sobre mecanismos de uma justiça de transição.

Da análise de dispositivos das constituições de 1946 e 1967, além de emendas à constituição, atos complementares, atos institucionais e legislação infraconstitucional, com base em contribuições teóricas que consubstanciaram a compreensão da temática proposta, observamos que a construção política e jurídica do regime de exceção foi estrategicamente desenvolvida para o fim de assegurar legitimidade e constitucionalidade aos mecanismos de poder que se fundamentou no argumento revolucionário. Esta circunstância dificulta a adoção de mecanismos destinados a uma justiça de transição que transcenda a Lei de Anistia, pois os debates estão além da legislação infraconstitucional e se colocam no plano constitucional e, até mesmo, no limite, fora, não alcançáveis mesmo pela ordem constitucional, pois que há razões que são articuladas para o fim de posicionar a legitimação das mediadas de exceção ao fundamento precedente das cartas políticas, na configuração de um dado poder real, absoluto, fundamente, constituinte de uma nova ordem. Este é o desafio da justiça de transição: de um lado, a modulação de efeitos para encontrar o argumento irrefutável que, ao tempo em que preserva o que não pode ser

\footnotetext{
${ }^{130}$ As abordagens que seguirão a presente contarão, dentre outras, com os estudos realizados por José Murilo de Carvalho (Forças Armadas e política no Brasil. Rio de Janeiro: Jorge Zahar Ed., 2006) e de João Rodrigues Arruda (O uso político das Forças Armadas e outras questões militares. Rio de Janeiro: Mauad X, 2007).
} 
modificado (sob pena de desconstituir fatos históricos e atos jurídicos), e, de outro lado, proporcionar o reconhecimento do dano, a identificação de responsáveis e a persecução penal, a punição. Isso seria possível?

Porém, o desafio também tem uma conotação jusfilosófica: a formação de amplo consenso que deixe de lado apelos ideológicos e possa proporcionar reconciliação, mais profunda do que o perdão e mais significativa do que pagamento de uma dívida cinquentenária.

\section{REFERÊNCIAS}

AGAMBEN, Giorgio. Estado de exceção. São Paulo: Boitempo, 2011.

AGUIAR, Roberto Armando Ramos de. Os militares e a Constituinte: poder civil e poder militar na Constituição. São Paulo: Alfa-Ômega, 1986.

ARENDT, Hannah. Origens do totalitarismo: antissemitismo, imperialismo, totalitarismo. São Paulo: Companhia das Letras, 2013.

ARRUDA, João Rodrigues. O uso político das Forças Armadas e outras questões militares. Rio de Janeiro: Mauad X, 2007.

BOBBIO, Norberto. Estado, governo e sociedade: por uma teoria geral da política. São Paulo: Paz e Terra, 2007.

BOETIE, Etiènne de La. Discurso da servidão voluntária. São Paulo: Martin Claret, 2010.

BRASIL. Constituição dos Estados Unidos do Brasil de 18 de setembro de 1946. Disponível em: <www.planalto.gov.br > . Acesso em: 17 fev. 2015.

BRASIL. Ato Institucional $\mathrm{n}^{0} 1$, de 09 de abril de 1964. Modifica a Constituição do Brasil de 1946 quanto à eleição, ao mandato e aos poderes do Presidente da República; confere aos Comandantes-em-chefe das Forças Armadas o poder de suspender direitos políticos e cassar mandatos legislativos, excluída a apreciação judicial desses atos; e dá outras providências. Disponível em: <www.planalto.gov. br >. Acesso em: 20 fev. 2015. 
BRASIL. Ato Institucional no 2, de 27 de outubro de 1965. Mantem a Constituição Federal de 1946, as Constituições Estaduais e respectivas Emendas, com as alterações introduzidas pelo Poder Constituinte originário da Revolução de 31 de março de 1964, e dá outras providências. Disponível em: <www.planalto.gov.br >. Acesso em: 17 fev. 2015.

BRASIL. Lei $\mathrm{n}^{0}$ 5.449, de 04 de junho de 1968. Declara de interesse da segurança nacional, nos termos do art. 16, $\S 1^{\circ}$, alínea "b", da Constituição os Municípios que especifica, e dá outras providências. Disponível em: <www.planalto.gov.br>. Acesso em: 20 fev. 2015.

BRASIL. Ato Institucional $\mathrm{n}^{\circ}$ 5, de 13 de dezembro de 1968. São mantidas a Constituição de 24 de janeiro de 1967 e as Constituições Estaduais; O Presidente da República poderá decretar a intervenção nos estados e municípios, sem as limitações previstas na Constituição, suspender os direitos políticos de quaisquer cidadãos pelo prazo de 10 anos e cassar mandatos eletivos federais, estaduais e municipais, e dá outras providências. Disponível em: <www.planalto.gov.br> . Acesso em: 22 fev. 2015.

BRASIL. Ato Institucional $\mathrm{n}^{\circ} 6$, de $1^{\circ}$ de fevereiro de 1969 . Altera a composição e competência do Supremo Tribunal Federal, amplia disposição do Ato Institucional $\mathrm{n}^{\mathrm{o}} 5$, de 13 de dezembro de 1968 e ratifica as emendas constitucionais feitas por Atos Complementares. Disponível em: <www.planalto.gov.br> Acesso em: 20 fev. 2015.

BRASIL. Ato Institucional $\mathrm{n}^{\circ} 14$, de 05 de setembro de 1969. Dá nova redação ao parágrafo 11 do artigo 150 da Constituição do Brasil, acrescentando que não haverá pena de morte, de prisão perpétua, de banimento ou confisco, salvo nos casos de guerra externa, psicológica adversa, ou revolucionária ou subversiva nos termos que a lei determinar - esta disporá, também, sobre o perdimento de bens por danos causados ao erário ou no caso de enriquecimento ilícito no exercício de cargo, função ou emprego na administração pública direta ou indireta. Disponível em: <www.planalto.gov.br>. Acesso em: 19 fev. 2015.

BRASIL. Ato Institucional $\mathrm{n}^{\circ} 16$, de 14 de outubro de 1969. Declara a vacância do cargo de Presidente da República, visto que o seu titular, Marechal Arthur da Costa e Silva, está inabilitado para exercê-lo, em razão da enfermidade que o acometeu. 
Disponível em: <www.planalto.gov.br> Acesso em: 22 fev. 2015.

BRASIL. Decreto-Lei ${ }^{\circ}$ 898, de 29 de setembro de 1969 (revogado pela Lei ${ }^{\circ}$ 6.620, de 17 de dezembro de 1978). Define os crimes contra a segurança nacional, a ordem política e social, estabelece seu processo e julgamento e dá outras providências. Disponível em: <www.planalto.gov.br> Acesso em: 20 fev. 2015.

BRASIL. Lei $\mathrm{n}^{0}$ 6.620, de 17 de dezembro de 1978 (revogada pela Lei $\mathrm{n}^{0} 7.170$, de 14 de dezembro de 1983). Define os crimes contra a segurança nacional, estabelece sistemática para o seu processo e julgamento e dá outras providências. Disponível em: <www.planalto.gov.br>. Acesso em: 20 fev. 2015.

BRASIL. Lei $\mathrm{n}^{\mathrm{O}}$ 6.683, de 28 de agosto de 1979. Concede anistia e dá outras providências. Disponível em: <www.planalto.gov.br> Acesso em: 22 fev. 2015.

BRASIL. Lei $\mathrm{n}^{0} 7.170$, de 14 de dezembro de 1983 (não consta revogação expressa). Define os crimes contra a segurança nacional, a ordem política e social, estabelece seu processo e julgamento e dá outras providências. Disponível em: <www. planalto.gov.br > . Acesso em: 20 fev. 2015.

BRASIL. Biblioteca da Presidência da República. Ex-presidentes. Disponível em: $<$ www.planalto.gov.br > . Acesso em: 18 fev. 2015.

BRASIL. Constituição da República Federativa do Brasil de 1988. Disponível em: $<$ www.planalto.gov.br > . Acesso em: 20 fev. 2015.

BRASIL. Decreto ${ }^{\circ}$ 849, de 25 de junho de 1993. Promulga os Protocolos I e II de 1977 adicionais às Convenções de Genebra de 1949, adotados em 10 de junho de 1977 pela Conferência Diplomática sobre a Reafirmação e o Desenvolvimento do Direito Internacional Humanitário aplicável aos Conflitos Armados. Disponível em: $<$ www.planalto.gov.br > . Acesso em: 21 fev. 2015.

BRASIL. Lei Complementar no 97, de 09 de junho de 1999. Dispõe sobre as normas gerais para a organização, o preparo e o emprego das Forças Armadas. Disponível em: <www.planalto.gov.br>. Acesso em: 21 fev. 2015.

BRASIL. Decreto $\mathrm{n}^{\mathrm{o}} 3.897$, de 24 de agosto de 2001. Fixa as diretrizes para o 
emprego das Forças Armadas na garantia da lei e da ordem, e dá outras providências. Disponível em: <www.planalto.gov.br> Acesso em: 21 fev. 2015.

BRASIL. Lei $\mathrm{n}^{\mathrm{0}} 10.875$, de $1^{\mathrm{o}}$ de junho de 2004 . Altera dispositivos da Lei $\mathrm{n}^{\mathrm{o}} 9.140$, de 4 de dezembro de 1995, que reconhece como mortas pessoas desaparecidas em razão de participação, ou acusação de participação, em atividades políticas. Disponível em: <www.planalto.gov.br> Acesso em: 22 fev. 2015.

BRASIL. Decreto $\mathrm{n}^{\mathrm{O}} \mathbf{5 . 4 8 4}$, de 30 de junho de 2005. Aprova a Política de Defesa Nacional, e dá outras providências. Disponível em: <www.planalto.gov.br>. Acesso em: 21 fev. 2015.

BRASIL. Decreto $\mathrm{n}^{0} 7.037$, de 21 de dezembro de 2009. Aprova o Programa Nacional de Direitos Humanos - PNDH-3 e dá outras providências. Disponível em: <www. planalto.gov.br > . Acesso em: 20 fev. 2015.

CARVALHO, José Murilo de. Forças Armadas e política no Brasil. Rio de Janeiro: Jorge Zahar Ed., 2006

FOUCAULT, Michel. Microfísica da poder. Rio de Janeiro: Graal, 1979.

KELSEN, Hans. O problema da justiça. São Paulo: Martins Fontes, 1998.

MACEDO JR., Ronaldo Porto. Carl Schmitt e a fundamentação do direito. São Paulo: Max Limonad, 2001.

SCHMITT, Carl. Teologia política. Belo Horizonte: Del Rey, 2006.

VIRILIO, Paul; SYLVERE, Lotringer. Guerra pura: a militarização do cotidiano. São Paulo: Brasiliense, 1984.

VIRILIO, Paul. Velocidade e política. São Paulo: Estação Liberdade, 1996.

VIRILIO, Paul. Estratégia da decepção. São Paulo: Estação Liberdade, 2000. 